\title{
Chitin as a Sorbent Superior to Other Biopolymers: Features and Applications in Environmental Research, Energy Conversion, and Understanding Evolution of Animals
}

\author{
Felix Blind and Stefan Fränzle *
}

check for

updates

Citation: Blind, F.; Fränzle, S. Chitin as a Sorbent Superior to Other

Biopolymers: Features and

Applications in Environmental

Research, Energy Conversion, and

Understanding Evolution of Animals.

Polysaccharides 2021, 2, 773-794.

https://doi.org/10.3390/

polysaccharides 2040047

Academic Editor: Azizur Rahman

Received: 16 July 2021

Accepted: 9 September 2021

Published: 9 October 2021

Publisher's Note: MDPI stays neutral with regard to jurisdictional claims in published maps and institutional affiliations.
International School Zittau (IHI), Department of Biological and Environmental Sciences, Dresden Technical University, Markt 23, D-02763 Zittau, Germany; felix.blind@gmx.de

* Correspondence: Stefan.fraenzle@tu-dresden.de

\begin{abstract}
Chitin is an effective sorbent which can be used in environmental monitoring, beyond obvious applications in withholding metal-containing pollutants from wastewater- or nuclear fuel reprocessing flows, since background levels in (purified) chitin are very low except for a few metals $\left(\mathrm{Fe}, \mathrm{Cu}, \mathrm{Al}, \mathrm{Ti}\right.$, and $\mathrm{Zn}$ ). Since retention of $\mathrm{M}^{\mathrm{x}+}$ and their complexes on chitin depend on an oxidation state, and to a lesser extent the presence of possible ligands or co-ligands, partition between chitin samples exposed to sediment and those exposed to water can be changed by environmental factors such as local biota producing or absorbing/metabolizing effective ligands such as citrate or oxalate and by changes of redox potential. Thermodynamics are studied via $\log \mathrm{P}$, using calibration functions $\log \mathrm{P}$ vs. $1 / \mathrm{r}$ or $\log \mathrm{P}$ vs. $\Sigma \sigma$ (sum of Hammett parameters of ligand donor groups) for di- and trivalent elements not involved in biochemical activity (not even indirectly) and thus measuring "deviations" from expected values. These "deviations" can be due to input as a pollutant, biochemical use of certain elements, precipitation or (bio-induced reduction of $\mathrm{SO}_{4}{ }^{2-}$ or $\mathrm{CO}_{2}$ ) dissolution of solids in sediment. Biochemical processes which occur deep in sediment can be detected due to this effect. Data from grafted chitin (saturation within $\leq 10 \mathrm{~min}$ ) and from outer surfaces of arthropods caught at the same site do agree well. Log $\mathrm{P}$ is more telling than total amounts retrieved. Future applications of these features of chitin are outlined.
\end{abstract}

Keywords: adsorption to chitin; complex formation; biomonitoring; charge (redox) fractionation; comparison of isolated chitin and arthropod covers; photoredox chemistry on chitin

\section{Introduction}

\subsection{Chitin and Chitosan-A Comparison of Chemical and Sorptive Properties}

Although chitosan, that is chitin which has undergone hydrolysis of acetamido side chains, is commonly used in medical applications and as a glue known to be inert (or get slowly dissolved and metabolized) in physiological terms [1,2], it

(a) does not occur in natural conditions and

(b) is much less robust against thermal or oxidative stress than the native chitin.

Chitin does adsorb all electrophilic agents such as metal ions [3], hydrocarbons [4] and anions such as arsenate, sulfate [5] or hexacyanoferrate which produce strong $\mathrm{H}$ bridges with $\mathrm{OH}$ groups of sugars. Even though the acetylation extent of chitin may vary (some 80-95\% [6]), it proved to display reproducible features as a sorbent (for quantitative terms see below). Chitin is difficult to oxidize both by an anode and by chemical agents such as the common agents for saccharide analytic cleavage; chitin itself is completely silent in electrochemical experiments (when dissolved by adding Li salts in dimethyl formamide) even though it does contain trace amounts of redox-active ions ( $\mathrm{Fe}, \mathrm{Ti}, \mathrm{Cu}$ ). It can be oxidized by certain staining agents such as $\mathrm{Ag}^{+}$or $\mathrm{OsO}_{4}$ only after deacetylation [6] while not being attacked by common reagents used in saccharide cleavage and analysis, such as 
$\mathrm{IO}_{4}{ }^{-}$or $\mathrm{Pb}(\mathrm{IV})$ acetate [7], both of which do react with the monomer, $\mathrm{N}$-acetyl glucosamine. However, alkaline oligoperiodate, identified as $\mathrm{H}_{2} \mathrm{I}_{2} \mathrm{O}_{10}{ }^{4-}$, does react, leaving behind chitin nanocrystals [8]. None of the said oxidants will occur in natural surroundings, however. Chitosan and monomers glucosamine and $\mathrm{N}$-acetyl glucosamine are degraded by both $\mathrm{IO}_{4}{ }^{-}$and $\mathrm{Pb}\left(\mathrm{CH}_{3} \mathrm{COO}\right)_{4}$. $\mathrm{Pb}(\mathrm{IV})$ acetate does not react with either chitin or (potato) starch, but with chitosan in DMSO/glacial acetic acid [7].

Thus, chitin is the material of choice if one wants to study sorbent properties concerning, e.g., trace metals in environmental analytics. Moreover, many different organisms, including such of meaningful operative surface sizes such as spiders [9], lichens $[3,10]$ or many insects, crabs, and crayfish are fully or partially covered by chitin which can in turn be sampled without necessarily killing the animals or lichens. The surface of grafted chitin surface used for adsorbing metal ions has a diameter of $1 \mathrm{~cm}$ and thus an active surface of some $0.78 \mathrm{~cm}^{2}$. Much smaller areas would suffice in a trade-off for sensitivity. Legs, wings, or mandibles of bigger arthropods will readily exceed this area. Chitin is much more robust towards pyrolysis than other biopolymers [11]. Degradation of natural chitin, containing proteins and metal carbonates, in moist environments, is distinguished by proteins removed first [12] while chitin may persist over $>>10^{8}$ years in some cases [12,13].

\subsection{Chemical Peculiarities Which Turn up at Ecotones and Similar Interfaces}

Generally speaking, chitin behaves as a very effective sorbent which even retains most metal ions at aq. levels $<1 \mathrm{nM} / \mathrm{L}$ ([14] and literature quoted there). Chitin can be dissolved in various solvents with (slow esterification by neat formic or dichloroacetic acids) or without permanent chemical modifications (hexafluoroisopropanol [15], carboxamides or lactams containing high levels of Li salts [14]), permitting production of fibers or films upon addition of water (all these solvents are completely miscible with $\mathrm{H}_{2} \mathrm{O}$ ). Different oxidation states may differ in their retention properties, such as with di- and trivalent $\mathrm{Eu}\left(\mathrm{Eu}^{2+}\right.$ being eluted from chitin by slowly running water or DMF). Thus, photo- or electroredox reactions taking place next to a chitin layer in flowing water will produce a voltage due to a concentration gradient which exceeds the electrokinetic flow potential (zeta potential) by a factor of 10 at least (the pzzp of chitin is $\mathrm{pH} \approx 4.6$ [14], considerably lower than the $\mathrm{pH}$ values obtained in water with carboxylate ions or even ethanol amines $\left.\left[\mathrm{C}_{\text {substr. }}=0.1 \mathrm{~mol} / \mathrm{L}\right]\right)$. Aq. arthropods other than water mites, caddisfly larvae [15] or Asellus aquaticus would not withstand $\mathrm{pH}<3.5$ for long either [16]).

Chitin does report on non-equilibrium phenomena next to water-sediment interfaces in a unique manner. These are caused by biological uptake or precipitation of certain elements in sediment [14], distinguishing part of benthic animals exposed to water only or penetrating the sediment-water interface regularly (i.e., antennae and leg tips of crayfish [17]). A rigorous formal analysis of partition data calibrated against "inert" di- and trivalent cations, respectively, yields much more information (see below). In addition, adsorption of $\mathrm{M}$ to chitin was studied depending on presence of such ligands which can be expected in soil liquids, ambient (fresh) waters or mining leachates. None of these features is present in chitosan or any other native or modified biopolymer, including cellulose (moss-based biomonitoring) or proteins. Hence, it is worthwhile to describe methods and results concerning chitin within this framework, too.

Although chitin does undergo slow surface hydrolysis, significant change of metal ion adsorption properties is limited to a few elements $(\mathrm{Y}, \mathrm{Pb}, \mathrm{Bi})$. "Normal" (crustacean) chitin (non-digging crayfish species Orconectes limosus) compares well to grafted chitin samples once exposed to boiling water; this was conducted either to euthanize crayfish caught alive for studying adsorption from either water or sediment depending on body parts/organs and their position/function in situ, or for comparison of data using grafted chitin. This does imply hydrolysis is negligible insofar as changes of complexation are concerned. Metals forming very stable ammin-, amine complexes such as $\mathrm{Ni}$ and $\mathrm{Cu}$ actually display a slight effect on adsorption after heat treatment of chitin samples. To put it the other way round, we still deal with chitin rather than chitosan after the chitin surface or animal had 
been (briefly) exposed to boiling water (see below). Apart from this, chitin is exceptionally robust in terms of thermal treatment, unlike other biopolymers [3,12].

Using this property of chitin takes one beyond simply deriving some relationship between adsorbed ion quantity and environmental concentrations. In fact, non-equilibrium states can be detected by comparing adsorption at adjacent sites (partition) and using transport. This feature is unique in biomonitoring. This is shown in the following diagrams. This can be observed at a water/inundated sediment interface. When biological activity or precipitation of solids cause "downward" (water $\rightarrow$ sediment) diffusion, the partition coefficient will increase, meaning more is adsorbed on chitin exposed to sediment (green arrow in Figure 1):
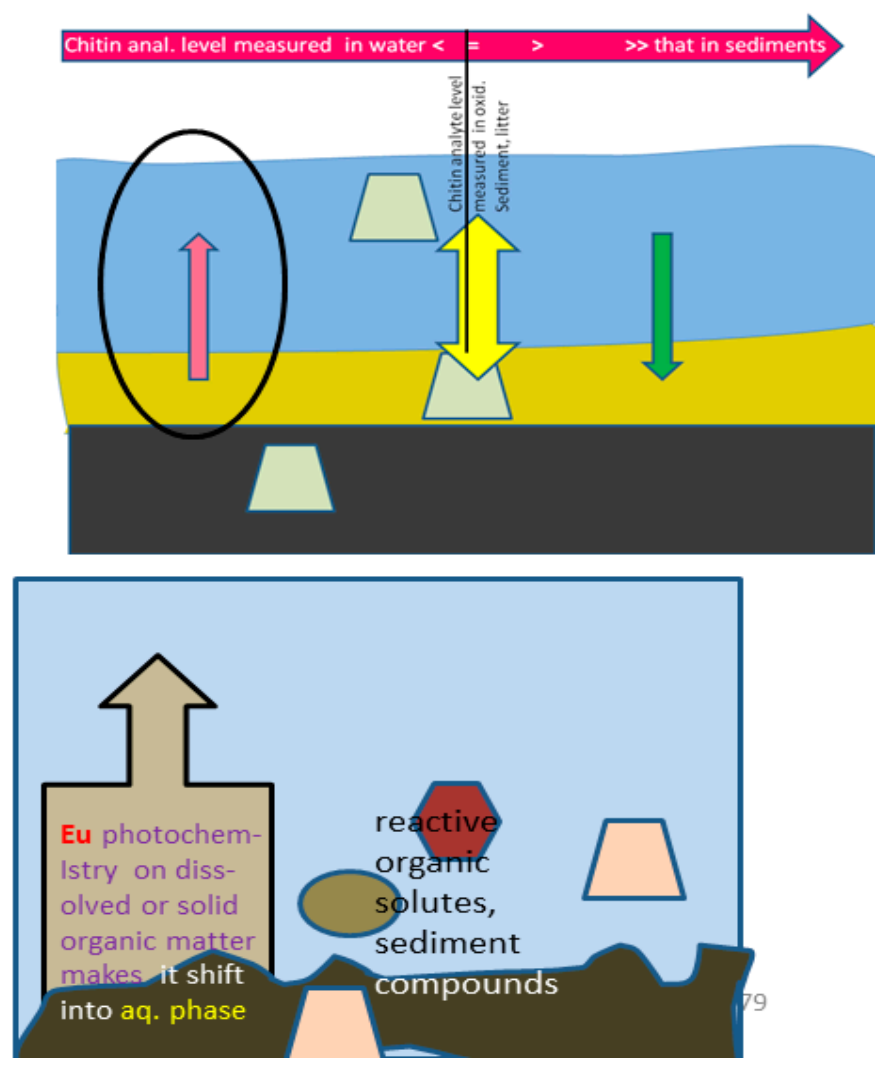

Figure 1. Partition of metals on chitin flakes embedded in water (top) and sediment (below) and corresponding effects concerning europium (Eu) co-illuminated with organic matter and photooxidizing it. Violet upward-pointing arrow refers to removal of $\mathrm{Ba}$ and $\mathrm{Pb}$ from sediment and depletion on the chitin flakes located there. The green downward arrow may be due to either input from above (limnetic or aerosol) or uptake deeper in the sediment. By this method one can detect processes which occur at least $40 \mathrm{~cm}$ from the interface, including methanogenesis linked to Ni which otherwise is too scarce to effect it without aerial input in ombrotrophic bogs. It does not matter whether this is the bottom of some water pool or its beach.

\section{Materials and Methods}

The procedure of sample processing and extraction of data was described before $([14,17,18])$. Surface dissolution is conducted using $\mathrm{LiClO}_{4}$ solutions in DMF, and absorption of this solute by cation exchanger resins kept in home-built Nylon baglets [17]. Backward ion exchange is achieved by flushing the bag several times by $1 \%$ aq. nitric acid subsequent to ion exchange which permits direct ICP-MS measurements (and re-use of the ion exchanger bag if wanted $[17,18])$. Amounts of reagent and periods of time in the workup steps were conducted according to the optimization procedures given by $[14,17,18]$. ICP-MS was undertaken by a Perkin-Elmer DR-Ce, not using the reaction cell. Detection limits were exceeded by far also for most REEs and other elements. A total of 26 elements 
was studied, omitting those which are abundant in biomass, yet do not bind to chitin (alkali metals, $\mathrm{Mg}$, Ca) [14]. Solutions of chitin prepared in this manner do also bind metal ions up to a comparable amount. When doing electrochemistry with such a solution, metal ions (if exceeding chitin saturation), chitin adducts and complex chitin adducts all do contribute to an electrochemical signal which can be determined by means of cyclic voltammetry. An example is given in Figure 2:

Whereas both metal (e.g., Fe like in this example) ions and complexes can be adsorbed to chitin, the latter may or may not adsorb without exchange of ligands other than halides. This enhancement effect was demonstrated recently in a simple experiment by these authors: after dissolving (anhydrous) $\mathrm{FeCl}_{3}$ in $40 \mathrm{~mL} \mathrm{DMF} \mathrm{(2.7} \mathrm{mM/L),} \mathrm{same} \mathrm{amount} \mathrm{(i.e.,}$ $100 \mu \mathrm{mol}=7.5 \mathrm{mg}$ ) of solid acetohydroxamic acid $\mathrm{CH}_{3} \mathrm{CON}(\mathrm{H}$ )-OH (causing immediate color change, meant to represent exudates from soil fungi or bacteria) and finally $20 \mathrm{~mL}$ of a saturated solution of shrimp chitin in DMF $\left(1.6 \mathrm{M} \mathrm{LiClO}_{4}\right)$ were added.

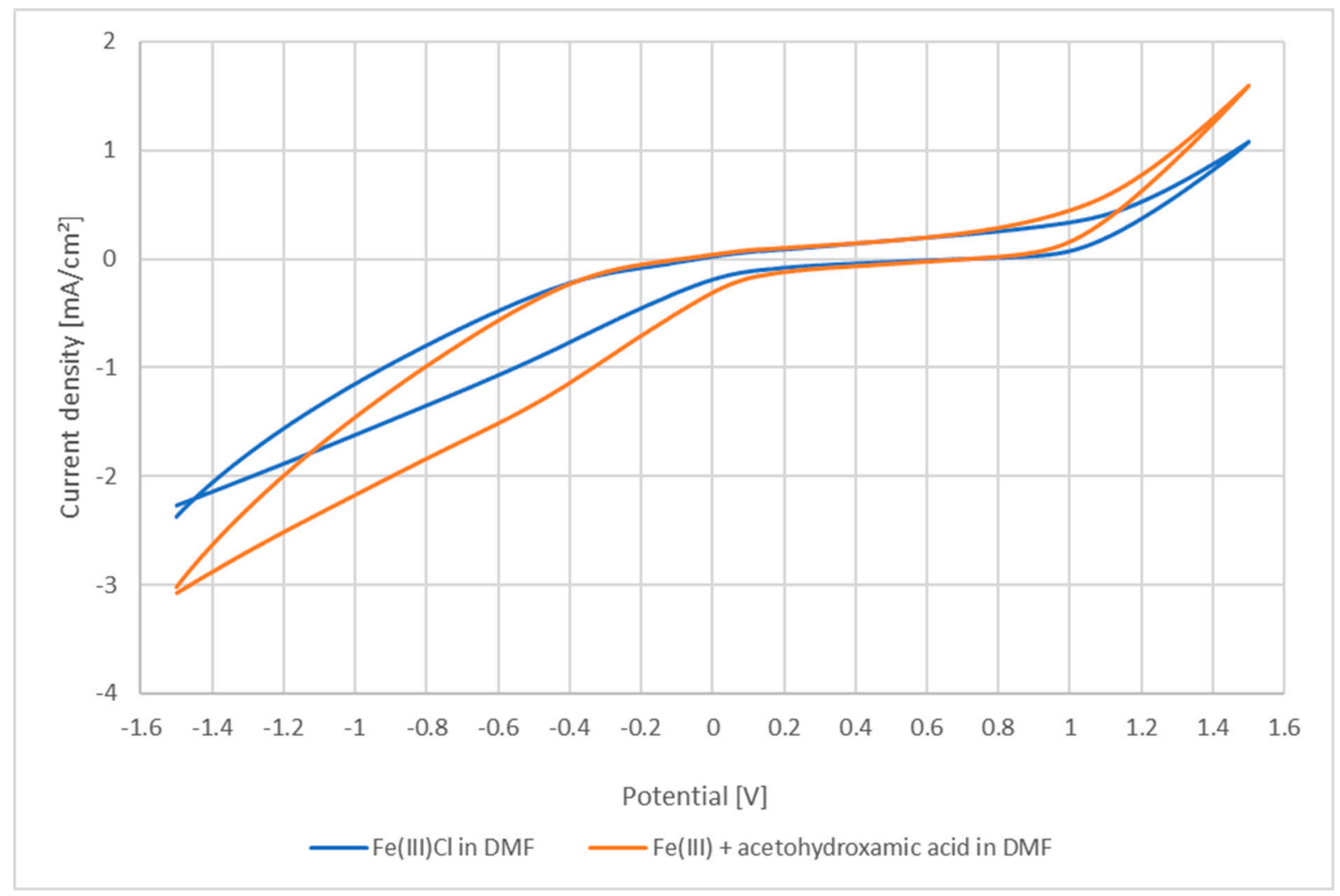

(a)

Figure 2. Cont. 


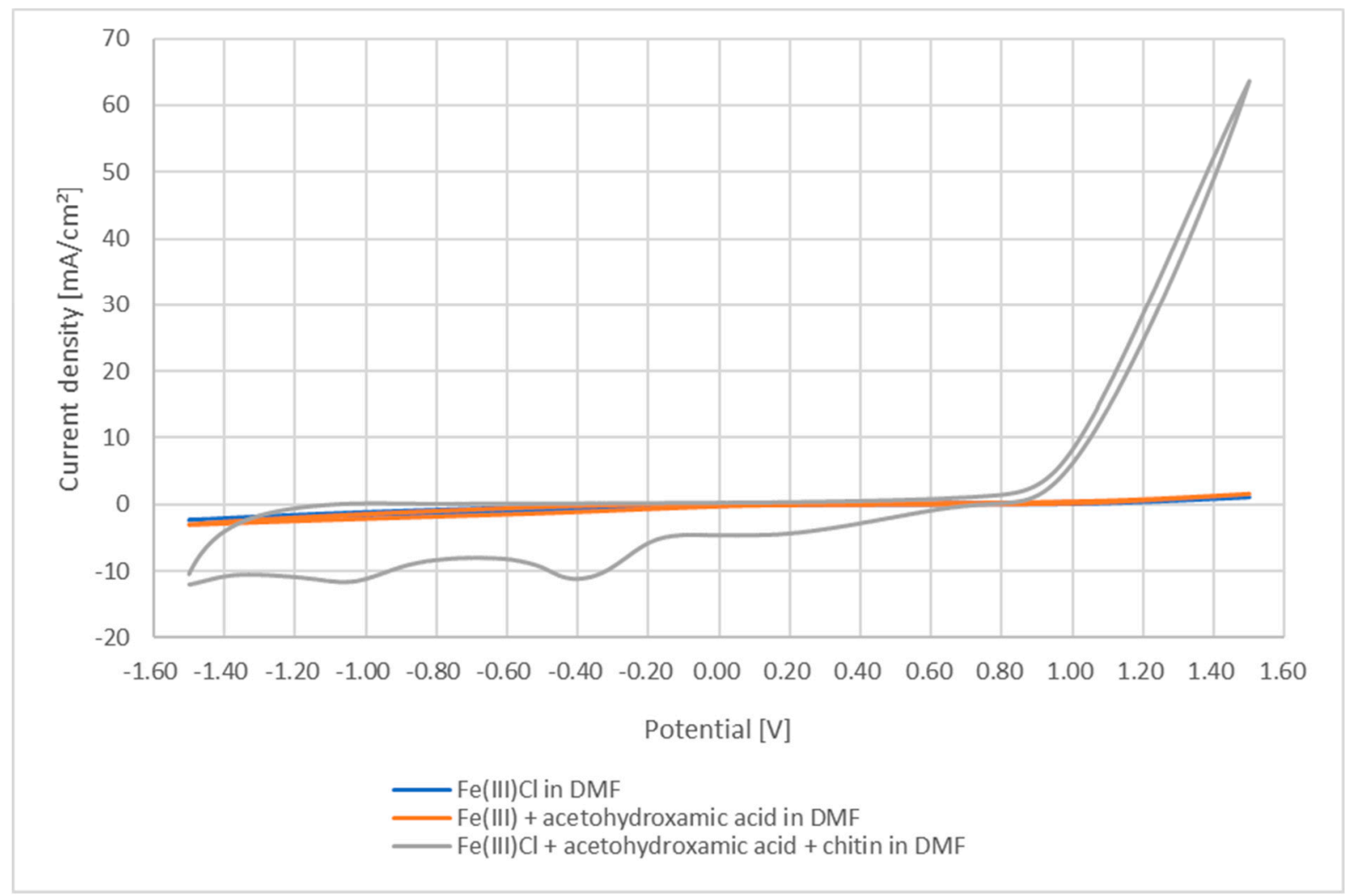

(b)

Figure 2. (a): Electrochemical behavior of $\mathrm{FeCl}_{3}$ dissolved in DMF (cp. [18,19]) as such and after adding acetohydroxamic acid. (b): Superposition of all three redox systems between -1.5 and $+1.5 \mathrm{~V}$ vs. SCE. Chitin adsorption does markedly increase measured current by organizing the redox system near electrode. Smell of solution indicates that a terminal $(\varepsilon \geq 0.9 \mathrm{~V}$ vs. SCE) increase in irreversible oxidation current is due to decay product dimethyl amine (for its oxidation properties cp. [20]).

The main redox transition of $\left[\mathrm{Fe}\left(\mathrm{CH}_{3} \mathrm{CO}-\mathrm{N}(\mathrm{H}) \mathrm{O}\right)\right]^{2+}$ at $-0.4 \mathrm{~V}$ remains at its position but becomes both stronger and irreversible, indicating desorption of $\mathrm{Fe}^{2+}$ from chitin. In the original solution there are just two species, namely partially hydrated $\mathrm{FeCl}_{2}{ }^{+}$and $\left[\mathrm{FeCl}_{4}\right]^{-}$solvated by DMF [21]. The effect of enhancing electrochemical activity may be important for both fuel cell applications and electroanalytical sensor methods (see below).

\subsection{Technique of Sampling}

Sampling was conducted by either grafted chitin [14] and/or collecting arthropods [17,22], lichens [10]. The former method is preferred for reasons of both

(a) protection of possibly endangered species and

(b) full control of exposition times while

The chitin sample can be located in either sediment or open water (it is recommended to mark chitin flakes placed in gravel- or other sediment by colored plastic strips or the like to improve the chances of retrieving them). Grafted chitin thus duplicates exposition features of "live" chitin whether or not the animal is a benthic one. Additionally, grafted chitin can be used in conditions by far exceeding those which would permit animals to survive, like excessive heat, cold, insecticides, radioactivity, etc., for most aquatic animals $\mathrm{pH}<3.5$ [16]. The latter fact allows detection of traces of contaminants, as well as determination of non-equilibrium states due to "uncommon" metabolic activities (i.e., such catalyzed by elements less common in biology). Typical examples are $\mathrm{Ni}$ (methanogenesis) or $\mathrm{V}$ (haloperoxidases, $\mathrm{N}_{2}$ fixation when Mo is depleted) or precipitation/dissolution of insoluble salts. The latter may include biochemical activity, too, particularly when $\mathrm{Ba}$ or $\mathrm{Pb}$ 
sulfates are dissolved by reduction consuming $\mathrm{H}_{2}, \mathrm{CH}_{4}$, or other organics in inundated sediment (see below).

The sampling is least invasive; in fact, the technique was designed to sample the same individuals of living arthropods (cricket Gryllus assimilis) several times, just etching the surface a little bit without intoxicating or killing the animal (both for protection concerns and to obtain a baseline for a single animal before beginning active biomonitoring) [14,22]. The DMF $/ \mathrm{Li}^{+}$solution (employing the most simple and convenient tertiary carboxamide available) can reach/suspend chitin concentrations of some $30 \mathrm{~g} / \mathrm{L}$ solvent at $\geq 2 \mathrm{M} / \mathrm{L} \mathrm{Li}^{+}$ ( Li salt $=$ nitrate, chloride, bromide, perchlorate, trifluoromethane sulfonate but not acetate or other carboxylates which do not suspend chitin in DMF even at similar Li levels). This method was selected and optimized (times, concentrations) after experiments conducted in my workgroup to obtain films of materials dissolving surface chitin and its sorbates without working in a liquid medium gave disappointing results: f.e., when melting $\varepsilon-$ caprolactam or $\delta$-valerolactam (m.p. $=40^{\circ} \mathrm{C}$ ) and adding Li salts decomposition and carbonization invariably occurred when adding solid Li salts to the lactam melts before even making contact with chitin. The end was to finally remove the solidified lactam/nylon film containing chitin and the analytes from the surface. Hence the experiment could not be completed into testing the retention to some organic film ripped from the chitin support [23].

Such solutions of chitin in $\mathrm{DMF}\left(\mathrm{LiClO}_{4}\right.$ as a conducting salt) are completely silent in electrochemical terms ( $\varepsilon$ in between -2.6 up to $+1.73 \mathrm{~V}$ vs. SCE (onset potential of oxidative solvent breakdown in DMF and similar carboxamides) although there are traces of metals in native chitin which might undergo redox transitions within this range (10-20 ppm Fe, some $15 \mathrm{ppm} \mathrm{Ti}, 1.5 \mathrm{ppm} \mathrm{Cu}$ ). Redox transitions do only occur after addition of metal salts or complexes and can be used to study adsorption to (dissolved) polymer strands by adding little by little metal salt until the original transition in DMF turns up (saturation; effects of added or present ligands can be studied in the same manner).

\subsection{Processing of Data}

Thus, meaningful partition coefficients are defined using sets of elements (di- or trior tetravalent metals, As, Sb, Se, Ge, etc.) which are not involved in biology. Partition coefficients $\mathrm{P}$ of such elements are plotted against functions which relate to complex formation constants $\beta$ of "similar" complexes vs. Hammett's $\sigma$ constant or reciprocal ion radii $1 / r$. The equations depend on the assumption that

$$
\log P \sim \log \beta(M L)=a \times \log \beta+b
$$

for some "test" or "equivalent" ligand L. a and b are given in a table below; the sign a

Then, corresponding data for "active" elements are introduced (e.g., $\mathrm{Cu}, \mathrm{Zn}$ ) to calculate differences vs. the expected value. The same kind of shift happens when equilibrium is perturbed by photochemical processes (mediated $\mathrm{Eu}$ (bottom of Figure 1), or $\mathrm{U}$, then changing partition of either element) or by external redox processes, e.g., responding to strongly reducing conditions (Figure 6). These effects can be correlated with observations of enzyme-related product formation/substrate consumption along the interface. Examples from our work include $\mathrm{CH}_{4}$ formation vs. Ni distribution (open field: a bog located right on the Polish-Czech border W of Mt. Śniezka (Sudety Mountains)) and nitrate reduction vs. uptake of Mo (model study done in our lab; Figure 3): 

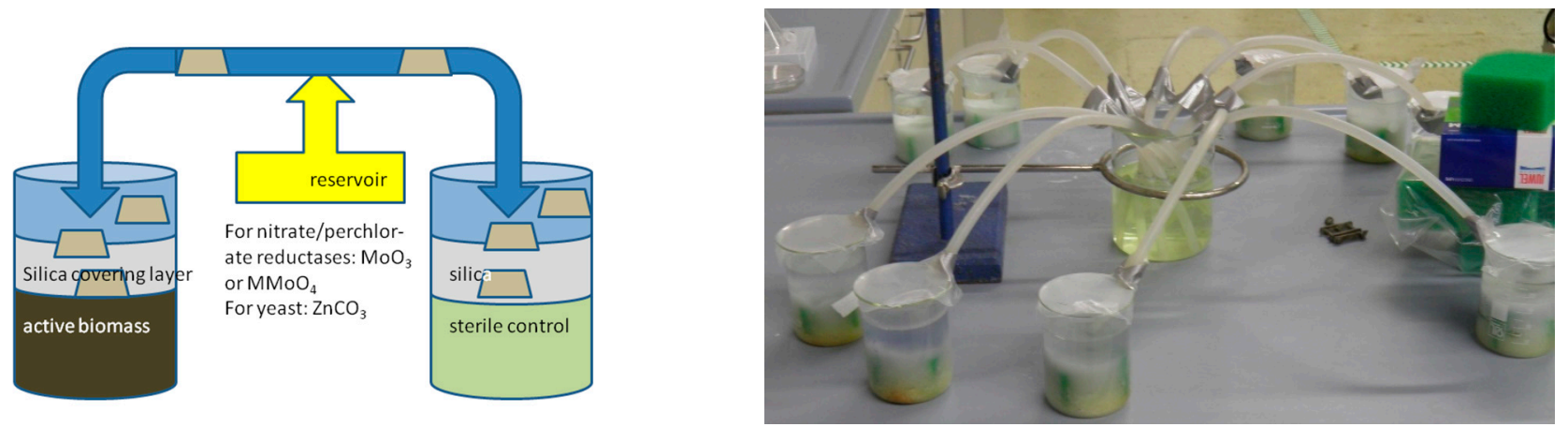

(central beaker with Mo stock solution connected to both active and inert [control] vessels)

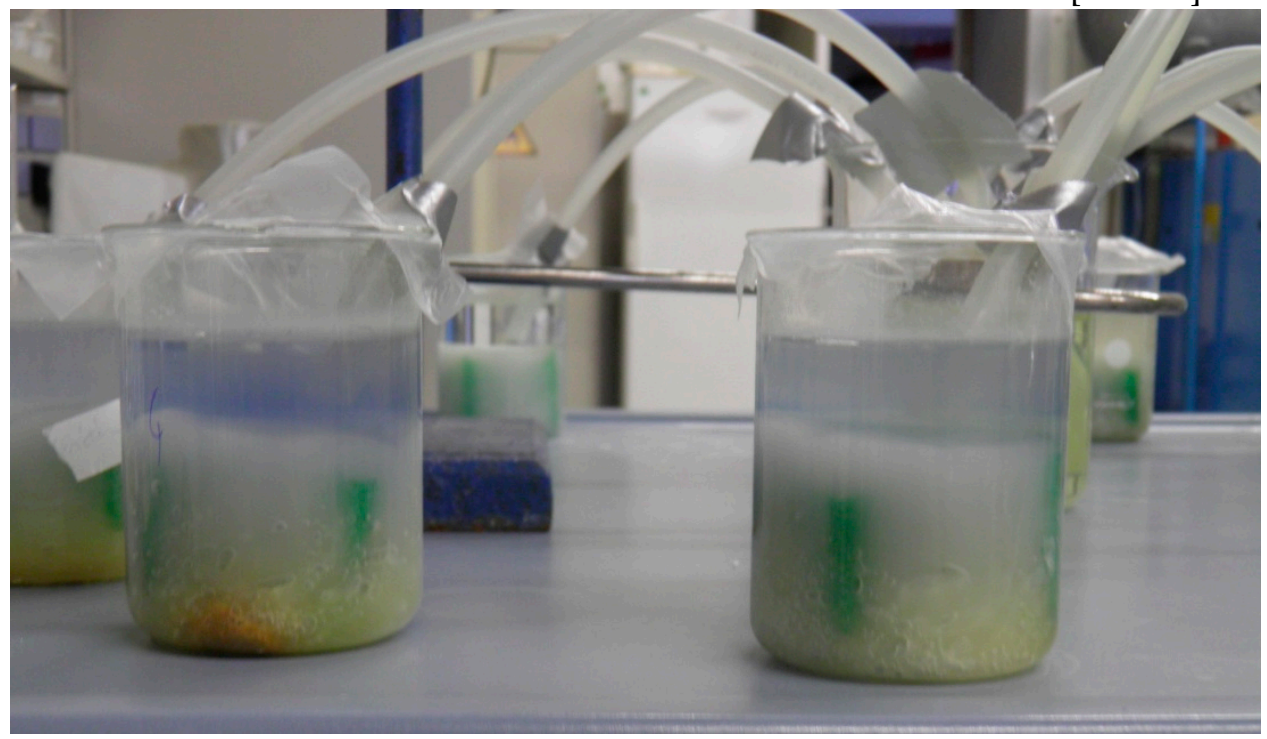

(active [left] and inert [right] vessels)

Figure 3. Transfer of Mo from central solution (pale yellow solution in central beaker in top right picture) via filled tubes to beakers where there is glucose, nitrate and nitrate reductase (bacterial pellets) or the latter is missing (sterile control). When there is biological activity, nitrate will be depleted while the levels of Mo inside silica layer are 2.5-2.9 times those on chitin placed in aq. supernatant. In controls (right), $\mathrm{P}_{\text {chitin;sedim./chitin; } \mathrm{H} 2 \mathrm{O}}<1.5$. Once nitrate is depleted, glucose keeps on reducing Mo turning the supernatant blue (bottom picture, left). Chitin flakes within tubes were omitted, transport occurring simply by diffusion, the "pump effect" of evaporation (and oxidation by $\mathrm{O}_{2}$ rather than $\mathrm{NO}_{3}{ }^{-}$) being limited by Parafilm ${ }^{\circledR}$ covers.

Possible reasons for non-equilibrium according to Figure 1 include photochemistry, biological/biochemical activity involving less-common and less-abundant metals and redox reactions which may cut linkage between chitin strands in either solid polymers or dissolved chitin.

The retention by chitin does also depend on oxidation state of an element. Thus, it will respond to redox or photoredox processes by changes of partition. Accordingly, some reduced $\left(\mathrm{Eu}^{2+}\right)$ or oxidized $\left(\mathrm{HCrO}_{4}^{-}\right)$forms of an element can be removed/extracted from the chitin layer by some slow flow of solvent, sometimes facilitated by light (reduction of $\mathrm{Eu}, \mathrm{U}$ ) or presence of a natural catalyst such as $\mathrm{MnO}_{2}$ that promotes air oxidations of Ce, $\mathrm{Cr}$ [24], $\mathrm{Cl}^{-}$, phenols [25], alkyl benzenes, etc., with both solid $\mathrm{Mn}$ phases [26] and $\mathrm{Mn}^{2+}$, although weakly adsorbing to chitin [22]). Then, two electrodes placed on either side of the percolated chitin pack will record different potentials due to the concentration drop (scheme Figure 4, practical setup Figure 5 below): 

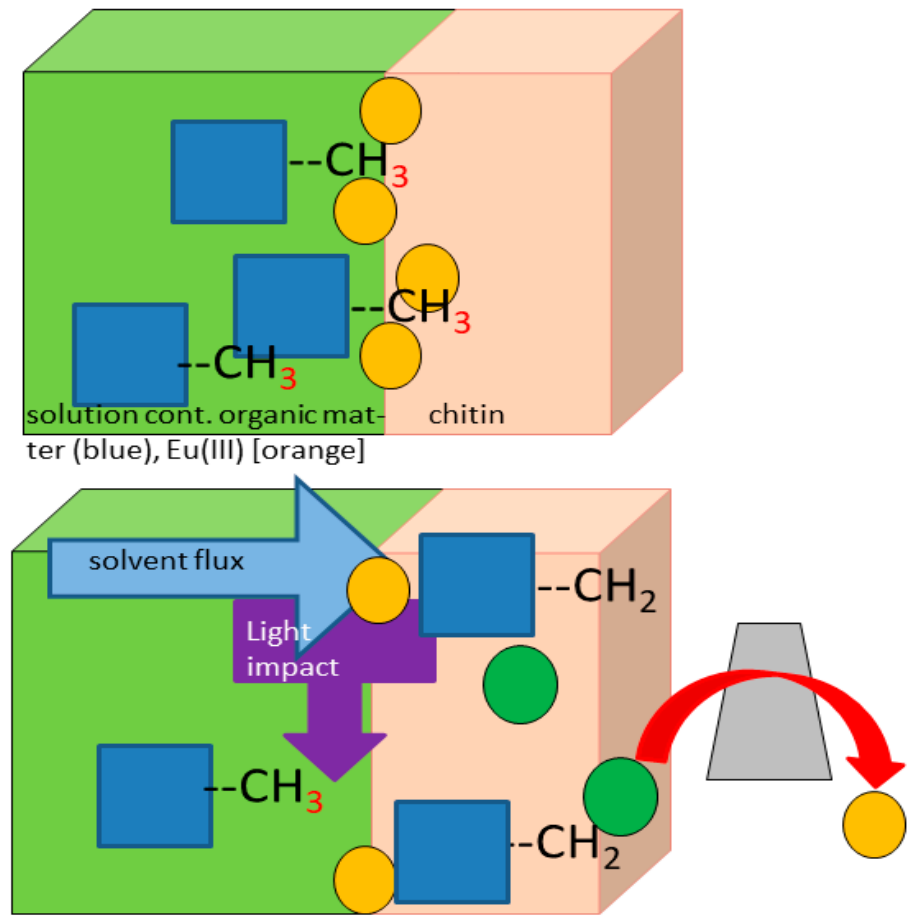

photoreactive methyl (-ene) compound $\left(\mathrm{CH}_{3} \mathrm{OH}, \mathrm{CH}_{3} \mathrm{OCH}_{2}-\right.$ $\mathrm{COOH}$, malonic acid) becomes radical, then transported into chitin layer along $\mathrm{Eu}^{2+}$

(green) by solvent flux, desorption

Figure 4. Eu can only pass the solvent/chitin-layer interface if reduced, otherwise it is retained by chitin surface.

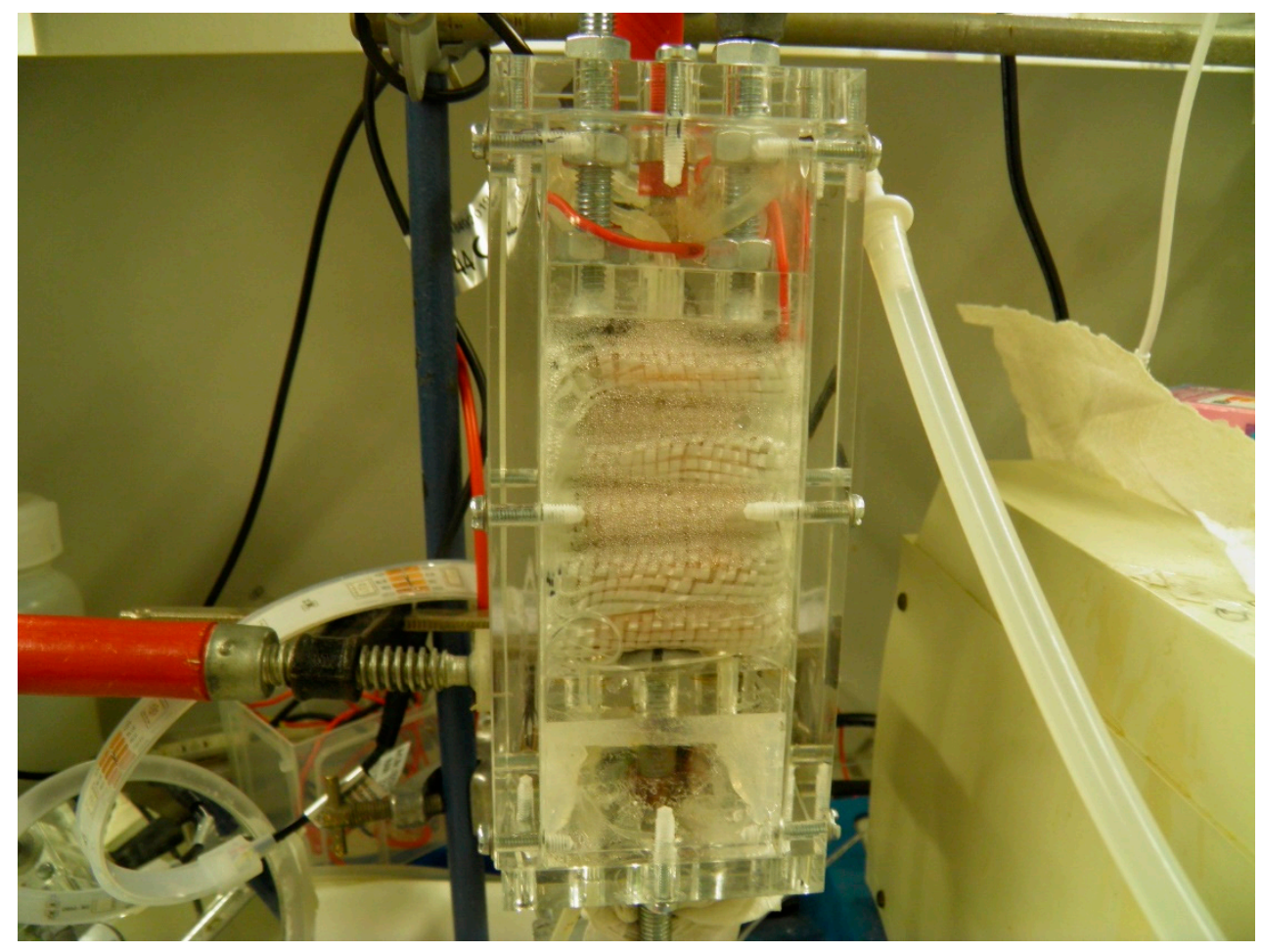

Figure 5. Design of a photo-assisted fuel-cell where excited Eu(III) does abstract hydrogen atoms from organic matter while the metalliferous product $\mathrm{Eu}^{2+}$ loses contact with/adsorption to chitin and is eluted "downward" to create an electrochemical potential like shown in Figure 3. When a reductant like ethanolamine spreads by diffusion in an open cell to reach $\mathrm{Eu}(\mathrm{III})$ at different times, initial potentials can be $>>100 \mathrm{mV}$ implying that $>99 \%$ of Eu are reduced by LED-light before the diffusion front reaches the counter-electrode also. The folded material is glass fiber fabric which was selected to be both inert and transparent for visible light (UV radiation is not required). 
Here, sensor technology and energy conversion-meant to induce fuel cell conversion of organic compounds containing $\mathrm{CH}$ and $\mathrm{NH}$ bonds while not requiring Pt group metals for $\mathrm{CH}$ bond activation and storing some light energy by making $\mathrm{Eu}^{2+}$ and $\mathrm{H}_{2}$ (in a secondary step)—do merge.

Beyond the statement that there is retention down to aq. $\mathrm{M}^{\mathrm{x}+}$ levels $<1 \mathrm{nM} / \mathrm{L}$, it is also feasible to compare chitin to a small ligand molecule the dative structure of which is very similar to that of chitin. One such ligand for which many complex formation constants are known is antibiotic agent chloramphenicol. Except for very simplified models of bidentate C-hydroxo/carboxamide (probably $\mathrm{O}$-) binding such as $\mathrm{N}$-formyl ethanolamine or $\mathrm{N}$-acetylethanolamine, the best-investigated ligand for which a reasonable number of complex formation constants are available is the antibiotic agent chloramphenicol ([27], introduced into clinical applications back in 1949), cp. the key structural motifs which are relevant for $\mathrm{M}^{\mathrm{n}+}$ complexation. The similarity of binding modes is shown in Figure $6 \mathrm{a}, \mathrm{b}$.

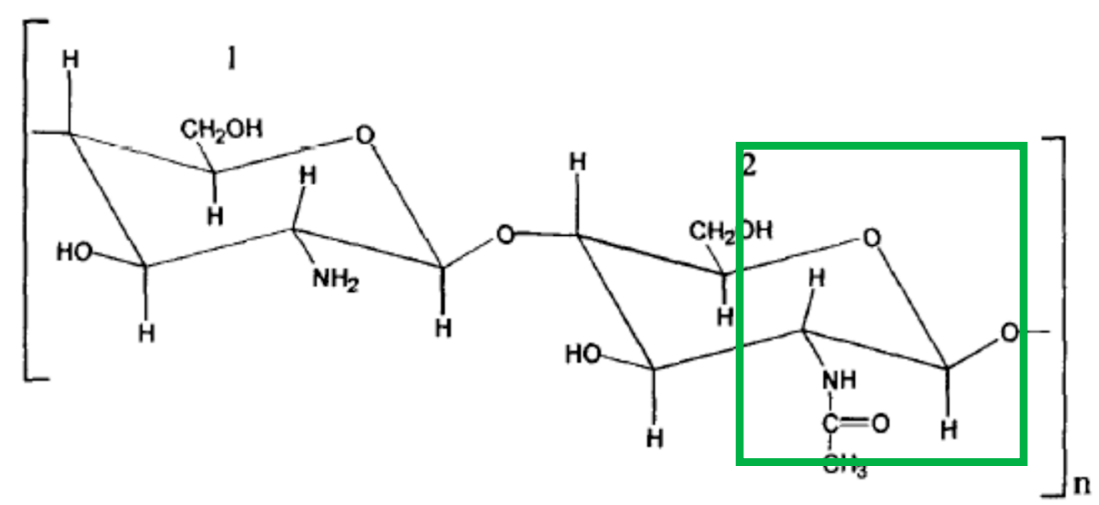

(a)

vs. chloramphenicol (bottom)<smiles>CC(O)(c1ccc([N+](=O)[O-])cc1)[C@H](CO)NC(=O)C(Cl)Cl</smiles>

(b)

Figure 6. (a): Chitin, displaying a free amino group at left saccharide ring $(<15 \%$ of total $\mathrm{N}$ in natural chitin samples, almost 100\% in chitosan). (b) Chloramphenicol: bidentate binding of metal ions via $\mathrm{OH}$ and carboxamide. For complex stabilities see Table 1, note similarity of binding motif. Dichloroacetamide will display a slightly increased $\mathrm{NH}$ acidity as compared with acetamide groups, thus possibly enhancing binding of metal ions like $\mathrm{Cu}, \mathrm{Pt}$ (cp. complexation properties of substituted hydantoins). 
Table 1. List of chemicals and materials used.

\begin{tabular}{|c|c|c|c|}
\hline Substance & Supplier & Purpose & Remarks \\
\hline chitin & $\begin{array}{l}\text { Sigma-Aldrich, Taufkirchen, } \\
\text { Germany }\end{array}$ & sorbent & $\begin{array}{l}\text { purified, background levels see text. } \\
\text { No electrochemical signal unless metal } \\
\text { salts were added }\end{array}$ \\
\hline Lithium perchlorate & $\begin{array}{l}\text { Sigma-Aldrich, Taufkirchen, } \\
\text { Germany }\end{array}$ & $\begin{array}{l}\text { Dissolution of chitin, } \\
\text { conducting salt in } \\
\text { CV }\end{array}$ & "battery-grade" purity \\
\hline Cation exchanger resin & $\begin{array}{l}\text { Amberlite } \mathrm{H}-120, \text { Supelco, } \\
\text { Bellefonte, PA, USA }\end{array}$ & $\begin{array}{l}\text { Fixation and transfer } \\
\text { of analytes }\end{array}$ & $\begin{array}{l}\text { Checked for trace metal background, } \\
\text { nothing detected. Can be re-used } \\
\text { several times after leaching ions bound } \\
\text { from chitin solution. Retrieval rate } \\
\text { about } 70 \%[18]\end{array}$ \\
\hline Nitric acid & $\begin{array}{l}\text { Merck Suprapur, Darmstadt, } \\
\text { Germany }\end{array}$ & & \\
\hline Crayfish Orconectes limosus & & & $\begin{array}{c}\text { Caught in local waters, also exuvia } \\
\text { were studied }\end{array}$ \\
\hline $\begin{array}{c}\mathrm{Eu}(\mathrm{III}) \\
\text { trifluoromethanesulfonate }\end{array}$ & $\begin{array}{l}\text { Sigma-Aldrich, Taufkirchen, } \\
\text { Germany }\end{array}$ & $\begin{array}{l}\text { Photooxidation } \\
\text { reagent }\end{array}$ & \\
\hline Solacor glue & $\begin{array}{l}\text { Boldt \& Co., Wermelskirchen, } \\
\text { Germany }\end{array}$ & $\begin{array}{l}\text { Fixation of chitin } \\
\text { flakes }\end{array}$ & $\begin{array}{l}\text { Photo-hardening, metal-free glue, } \\
\text { rather resistant towards organic } \\
\text { solvents including DMF }\end{array}$ \\
\hline
\end{tabular}

For the latter monomeric ligand the following complex formation constants (aq., $\mathrm{I}=0.1 \mathrm{M}, \mathrm{T}=25^{\circ} \mathrm{C}$ ) do hold (Table 2) ([27], except for lead and iron):

Table 2. Complex formation constants of $\mathrm{M}^{2+}$ ions, Fe(III) with chloramphenicol ([24] and other sources).

\begin{tabular}{ccc}
\hline $\mathbf{M}^{2+}$ & Log $\mathbf{k}$ & Remarks \\
\hline $\mathrm{Pb}$ & 3.26 & Pb does accumulate on chitin more than other metals [9,13] \\
\hline $\mathrm{Cd}$ & 3.93 & background on chitin essentially zero \\
\hline $\mathrm{Mn}$ & 3.54 & \\
\hline $\mathrm{Ni}$ & 3.33 & Detection of methanogenesis \\
\hline $\mathrm{Zn}$ & 3.16 & different oxidation state \\
\hline $\mathrm{Fe}(\mathrm{III})$ & 4.13 & \\
\hline
\end{tabular}

The corresponding calculated electrochemical ligand parameter is- $0.154 \mathrm{~V}$ (bidentate binding). This value would correspond to $\log \mathrm{k} \approx 5.7$ for binding of $\mathrm{Cu}(\mathrm{II})$ to chitin using the formula introduced by this author [28]:

$$
\log \beta=x \times E_{L}(L)+c
$$

with $x$ and $c$ tabulated in $[28,29]$. Equation (2) is formally equivalent to (1) since there is some linear relationship between Hammett's constant $\sigma$ and the electrochemical ligand parameter [30,31], as defined by Lever [31] (there are also other scales/benchmark redox systems but these comprehend far less ligands), whereas $\mathrm{x}$ and $\mathrm{c}$ are linearly correlated and thus can be traced to Equation (1) by corresponding coefficients (suggested in [30] without actually revealing correlation equations). Understanding LREE binding to chitin is most important because it offers the only sizable dataset for trivalent ions (besides of $\mathrm{Al}, \mathrm{Cr}, \mathrm{Bi}$ ) unless there is biocatalytic activity associated with some of them [32-35], and because of its application in fuel cells and sensor devices (see below). 
However, both $\mathrm{x}$ and the slope of the latter equation (not explicitly given by [30])

$$
\mathrm{E}_{\mathrm{L}}(\mathrm{L})=\mathrm{e}_{\mathrm{nd}} \times \Sigma \sigma+\mathrm{f}_{\mathrm{nd}}[\mathrm{V}]
$$

(parameters calculated by SF [36]) depend on denticity d and charge of ligand. Thus, a couple of parameters is required rather than a single set, given in the following Table 3:

Table 3. Relationship between $\sigma$ and electrochemical ligand parameter for different kinds of ligands.

\begin{tabular}{ccccc}
\hline Kind of Ligands & $\begin{array}{c}\text { No. of Ligands in } \\
\text { Regression }\end{array}$ & $\mathbf{e ~ [ \Sigma \sigma ]}$ & $\mathbf{f}[\mathbf{V}]$ & Remarks \\
\hline Monodentate, neutral & 7 & 0.278 & 0.124 & $\begin{array}{c}\mathrm{N}-, \mathrm{P}-, \text { As-, S- and C- (isocyanides) donors, which all } \\
\text { are } \pi \text {-bonding }\left(\mathrm{NH}_{3} \text {, aliphatic amines do not }\right. \\
\text { correlate properly) }\end{array}$ \\
\hline $\begin{array}{c}\text { Monodentate anions } \\
\text { Bidentate, different } \\
\text { charges }\end{array}$ & 15 & 0.265 & 0.133 & omitting pyridine, plus $\mathrm{AsPh}_{2}\left(\mathrm{CH}_{3}\right)$ \\
\hline & 6 & 0.593 & -0.402 & $\begin{array}{c}\text { Halides, pseudohalides including } \mathrm{CN}^{-}, \mathrm{OH}^{-}, \\
\text {carboxylates, etc., not } \mathrm{H}^{-}\end{array}$ \\
\hline
\end{tabular}

The advantage of (1) is that many more Hammett constants $\sigma$ are available (e.g., [28]) than electrochemical ligand parameters $[10,29,31]$.

Most Hammett parameters were taken from literature [31] while complex stability constants for benzene-1,2-dicarboxylic (ortho-phthalic) acid anion, salicylate, and maleate $(\mathrm{M}=\mathrm{La}, \mathrm{Nd}$, and $\mathrm{Eu}[37])$ gave the following additional values for $\sigma^{\prime}$ (Table 4):

Table 4. Hammett constants of different ligands (calculated using [13]).

\begin{tabular}{ccccc}
\hline $\begin{array}{c}\text { Ligand } \\
\text { (Bidentate) }\end{array}$ & $\boldsymbol{\Sigma} \boldsymbol{\sigma}$ & $\boldsymbol{\sigma}^{\prime}$ & $\begin{array}{c}\boldsymbol{\Sigma} \text { of "Normal” } \\
\text { Ligands }\end{array}$ \\
\hline o-phthalate & -0.36 & -0.18 & $\begin{array}{c}\text { Carboxylate 0, } \\
\text { OH }-0.37\end{array}$ & \\
\hline salicylate & -0.40 & $\mathrm{OH}($ aromatic) $=-0.22$ & & $\begin{array}{c}\text { Cannot be broken } \\
\text { up as definition } \\
\text { applies to bidentate } \\
\text { ligands }\end{array}$ \\
\hline
\end{tabular}

An actual chitin polymer strand has $\mathrm{M}^{*} \approx 400.000$, and the structural motif binding $\mathrm{M}^{\mathrm{x}+}$ is present about 2000 times. Hence, actual complex formation constants (log) $\beta_{\mathrm{M} \text {; chitin }}$ are much higher than for complexation by chloramphenicol, agreeing to the fact that even $\mathrm{pMol} / 1$ levels cause measurable adsorption of element ions.

Chitin-based biomonitoring does require reliable and fast adsorption. In our experiments, equilibrium was usually reached within $10 \mathrm{~min}$. Earlier work had shown that even traces of 'heavy metals', including radionuclides [38] could be removed from water flows and slurries, causing us to explore chitin application chances in environmental analytics. Background levels of metals in commercial chitin obtained by shrimp peeling (Pandalus borealis; Sigma-Aldrich, Taufkirchen, Germany) are very low, permitting detections of traces of contaminants in ambient matter, too: levels of $\mathrm{Al}$, Ti, and Fe are some 10-20 $\mu \mathrm{g} / \mathrm{g}$ chitin; $\mathrm{Cu}$ and $\mathrm{Zn}$ come with about $1.5 \mu \mathrm{g} / \mathrm{g}$ regardless of the significant role of either metal in arthropods, while important toxic metals [22] such as Be, Cd, and $\mathrm{U}$ cannot easily be detected in the native material, implying almost any trace will be pinpointed. Binding capacity is about $40 \mu \mathrm{mol} / \mathrm{g}$ for most metals, while values for $\mathrm{Al}$ [22], Ce or Eu [39], V or $\mathrm{Pb}[14,22,40]$ are considerably higher. Most metals for which some biological role was 
established recently (e.g., [41]) bind rather well, so do Bi and certain others for which no (catalytic) biological role was detected so far.

\section{Results}

\subsection{Photoredox Processes and Retention}

Of course, complexation can alter the extent/equilibrium of metal ion retention. Many ligands, however, contain "free" terminal oxygen or nitrogen (carboxylate-, sulfate groups, unbound nitriles in AAN or cyanoanilines, etc.) which form $\mathrm{H}$ bonds with $\mathrm{OH}$ groups of the polysaccharide. Then, complexation will rather enhance retention of $\mathrm{M}^{\mathrm{x}+}$ to chitin. Since retention of metal ions by chitin is not just "all (most metal ions, -complexes, down to $<1 \mathrm{mM} / \mathrm{L}$ ) or nothing (alkali metals, $\mathrm{Mg}, \mathrm{Ca}$ )", binding rather depends on oxidation states, too; there can be both energy conversion (subsequent to redox- or photochemical changes of oxidation state) and some effect-not generally a perturbation-on adsorption for analytical purposes. Because levels of these ligands used to be low, this does not compromise results on $\mathrm{M}$ in normal lakes or ponds. However, it should be noted that the above change of partition might also extend to LREEs as the latter, especially La and $\mathrm{Nd}$, are involved in oxidation of methanol $[33,34]$ and other primary alcohols run by aerobic proteobacteria [35]; that is, this will happen right in the uppermost sediment layer. Except for this case, REEs can be taken—such as and adding to $\mathrm{Al}, \mathrm{Cr}$, Bi-to represent physiologically inert $\mathrm{M}^{3+}$ for production of such a calibration function. With $\mathrm{M}^{2+}$, it can be $\mathrm{Sr}, \mathrm{Ba}, \mathrm{Co}, \mathrm{Ni}$ (at sufficiently high potentials which preclude methanogenesis [40]), $\mathrm{Pb}$, or $\mathrm{Cd}$. $\mathrm{Mg}$ and $\mathrm{Ca}$ do not bind to chitin, whereas $\mathrm{Mn}, \mathrm{Cu}$, and $\mathrm{Zn}$ are involved in all life-forms (and thus shall generally "deviate" from the regression obtained in the above Equation (1) in favor of a stronger adsorption within sediment). However, $\mathrm{Ba}$ and $\mathrm{Pb}$ can be mobilized once there is sulfate reduction. There are no difficulties with coarse, gravellike sediments or beaches, but fine-grained sediments are more difficult to understand if inundated. Elements commonly occurring in oxidation states +IV and higher normally do not take part in biochemistry (except for Mo, $\mathrm{V}$, and sometimes $\mathrm{W}[40]$ ).

\subsection{Relationship between Donor Groups and $\log \sigma_{\text {para }}$ or Log P Constants for Metal Coordination to Chitin}

It is an interesting case to compare chitin in its "physiological place"-covering aquatic or moisture-exposed arthropods (like crayfish, shrimps, ants or bumblebees building nests in moist soil) - to isolated and grafted chitin samples: will adsorption patterns match insofar as measurements on living beings can be attributed to sample either the aq. phase or sediment (which means crayfish to be studied must not dig tunnels in which they live, hide or even reproduce). As can be seen from Table 4, differences against the simple aq. system are small enough to analyze adsorption chemistry/selectivity along the common way of reasoning but large enough to observe effects due to local chemistry. There are no indications for isotopic fractionation of multi-isotopic elements during chitin adsorption; for example, determinations of Sm content on chitin surfaces using isotopes ${ }^{147} \mathrm{Sm},{ }^{149} \mathrm{Sm}$, and ${ }^{152} \mathrm{Sm}$, respectively, provide the same result assuming the normal isotopic composition of samarium [18]; (this does likely permit to reconstruct the whereabouts of chitin-covered organisms by means of $\mathrm{Pb}$ [41] isotopic signature). Solvent impact may alter chitin structure [42]; acidity values of potential ligands (protonated forms thereof) in DMF are given in [43] and were used besides own measurements to derive Equations (9) and (10).

Given the binding groups of chitin (or that in any other polymeric ligand) are either obvious (say, in polyacrylonitrile, all being - $\mathrm{CN}$ ) or can (must) be inferred from complex formation studies, the following equation (4) can be used to accomplish, with (5), referring to partition and assumed to be equivalent to (4), polymer-metal ion interactions which are taken to happen by complexation, with or without additional ligands involved:

$$
\log \beta=a \times \sigma_{\text {para }}+\mathrm{b} \text { and }
$$




$$
\log \mathrm{P}=\mathrm{a} \times \Delta \sigma_{\text {para }}
$$

where $\sigma_{\text {para }}$ is Hammett's constant (for para substitution and log P denotes the partition between chitin samples immersed into sediment and adjacent water (e.g., at bottom of some pond or creek or at a beach or bog pool lining), tacitly assuming metal binding to chitin occurs by complexation as with ligands dissolved in some solvent (this is to account for the large differences in metal retention by chitin and by either chitosan or cellulose). Data for meta substitution (e.g., [31]) are linearly correlated with $\sigma_{\text {para }}$; however, considerably less values are available for $\sigma_{\text {meta. }}$. Some $\sigma_{\text {para }}$ values must be modified as metal ions may bind to ligands in manners not available to withhold the aromatic groups such as phenyl or naphthyl. This also holds for carboxamide or 3-ketoenolate ligands which interact via O with metal ions, rather than forming CC bond, as well as carboxylates, nitrate, sulfate, etc. which would form esters or acid containing a C-O-E or HO-E single bond chain whereas $\mathrm{REE}^{3+}$ will bind via two $\mathrm{O}$ atoms, which is why there are different descriptions for REE ions.

Equation (3) can be rearranged to calculate an effective value of $\sigma$ or $\Sigma \sigma$ even without knowing the binding functions, or in cases where $\mathrm{M}$ ligation differs from binding modes to aromatics, such as carboxamide or 3-ketoenolate ligands:

$$
\begin{aligned}
\log \beta-b & =a \times \sigma_{\text {para }} \text { and thus } \\
\sigma_{\text {eff }} & =(\log \beta-b) / a
\end{aligned}
$$

Hence, $\log P$ represents the difference of local chemical conditions between the two phases connected by an ecotone while $\log \beta$ refers to complexation of the ion in the same solvent. This does mean the equilibrium state shown in Figure 1 (yellow double arrow) can exist for $\log P \neq 0$ for respective parameters and ion sizes.

\subsection{Effects of Boiling Water on M Retention}

Generally speaking, chitin is very robust against both thermolysis (wet or dry) $[12,13]$ and oxidation $[7,14]$. This holds for both chemical, using the colloquial reagents for polyor monosaccharide analysis (which, however, do readily react with chitosan, see above) such as periodate or $\mathrm{Pb}(\mathrm{IV})$ acetate, and electrochemical processes (own experiments in DMF solvent containing $\mathrm{Li}^{+}$). Yet, acetamide groups may be labile towards (hot) water hydrolysis (chitosan is prepared by rough (e.g., warm $\mathrm{NaOH}$ ) hydrolysis from chitin [2,6]). Such hydrolysis might occur when chitin is exposed to hot (boiling) water [17]. Effects from this were studied in both grafted chitin and crayfish (this is the regular method of euthanizing them, rather than applying chemicals). As a rule, the layer from which metal ions are mobilized by $\mathrm{DMF} / \mathrm{Li}^{+}$becomes thicker, and thus more metal ions are leached. Certain metals, however, show the opposite behavior, namely when amino groups produced by acetamide hydrolysis do better to bind metal ions, e.g., with Y, Ni or $\mathrm{Cu}$. Complexation of trace metals essential to microorganisms (too) by chitin or chitosan apparently do block growth/multiplication of pathogenic bacteria [44] or yeasts [45].

\subsection{Effects of Ligands on M Retention}

While effects of non-specified ligands were considered before in this paper, adsorption depending on ligand additions was studied for a couple of elements also [18] in the test medium (water $/ \mathrm{DMF} 50 / 50 \mathrm{v} / \mathrm{v}$, buffered to $\mathrm{H}_{0}=5.8$ by adding anilinium salts. We did study this for $\mathrm{M}=\mathrm{Mn}^{2+}, \mathrm{Ni}^{2+}$ [46], and six REEs (i.e., $\mathrm{La}, \mathrm{Ce}, \mathrm{Sm}, \mathrm{Eu}, \mathrm{Dy}$, and $\mathrm{Yb}$ [18], also covering $\mathrm{Mn}$ ). The only ion which generally does lose contact with chitin interfaces upon addition of ligands known or expected to be present in the soil solution (delivered by plant roots, fungal mycelia, or soil bacteria) is Sm(III) introduced as trifluoromethane sulfonate salt, like the other REEs [18]. The buffer was chosen to circumvent the problem that most buffers either do precipitate REEs or else undergo photooxidation by $\mathrm{Eu}(\mathrm{III})^{*}$ while retention by chitin depends on $\mathrm{pH}$ or $\mathrm{H}_{0}[14,22]$. La and Eu do better bind to chitin when glycine was added, while retention of both Ce and HREEs Dy, $\mathrm{Yb}$ is increased by 
adding anyone of many ligands, including humic acids. Some of them are photoactive with $\mathrm{Eu}(\mathrm{III})$ while others are not. This will change results of partition measurements (Figure 1 bottom), but it is included in calibration as these measurements were conducted in very dim light.

\subsection{Comparison to Chitin on Living Benthic Animals and Their Exuvia}

Data on antennae (comparing to open water) and other parts of benthic, non-digging crayfish Orconectes limosus showed highest accumulations (BCF values) for elements such as $\mathrm{Bi}, \mathrm{V}$, and light REEs from water [17] while sediment/water partition on both chitin flakes and crayfish cover parts which penetrate into sediment (leg tips, telson) is most pronounced for LREEs La, Ce. Knowing that adsorption of "integer" complexes prevails over that of $\mathrm{M}^{\mathrm{x}+}$ for $\mathrm{M} \neq \mathrm{Sm}$ in many/most cases [18], $\Sigma \sigma_{\text {para }}=-0.44$ for chitin in pure water and calculations from $\log \mathrm{P}$ of "bioinert" metals in different local waters are feasible. They give an idea of the size of changes caused by presence of (possibly ligating) organics in water and/or sediment of local waters. Samples were obtained in upper Lusatia, Saxony, FR Germany, representing mainly small ponds, lakes, and (lignite, gravel) quarry ponds, and beside small rivers (data from [17], here Table 5); water depth in sampling was $1 \mathrm{~m}$ or less:

Table 5. Partition factor $\mathrm{P}$ for chitin flakes and comparison telson/antennae, leg tips/antennae for calculation of effective $\Sigma \sigma$ (calculation from a, b for Al, La and Ce. $\Sigma \sigma$ does refer to aq. phase while $\Sigma \sigma^{\prime}$ denotes conditions in top sediment layers (leg tips, chitin flakes). $\mathrm{La}^{3+}$ does accumulate on flakes (FA) much more rapidly than in (leg tips of) living animals (LA) likewise immersed in sediment except when there is lignite. Animals were caught and exuvia collected next to the shore at water depths $\leq 1 \mathrm{~m}$ [17]. Exuvia were not "boiled", thus site VII gives a direct comparison on the effect of thermal treatment of chitin.

\begin{tabular}{cccccc}
\hline Site & Description of Site & $\Sigma \sigma$ & $\Sigma \sigma^{\prime}$ & Remarks & La Partitions (P) [-] \\
\hline I & $\begin{array}{c}\text { Pond, former lignite pit (12 m } \\
\text { max. depth), exuvia }\end{array}$ & -0.574 & -0.532 & $\begin{array}{c}\text { LA 1.27 } \\
\text { FA 0.39 }\end{array}$ & LA 1.45 \\
FA 6.00
\end{tabular}

Antennae (Orconectes limosus) are distinguished by $\Sigma \sigma$ somewhat lower than for both pure water-chitin and leg tips penetrating top sediment layers; the shift generally is negative and of order -0.1 to -0.2 . It is difficult to explain this value into much detail, yet this does mean local organic contributions will hardly change or limit application of the method. The two sets of effective $\Sigma \sigma$ are related according to Equation (8)

$$
\Sigma \sigma=-0.321 \Sigma \sigma^{\prime}-0.666
$$


obtained from linear regression of the above values. Accordingly, partition between (a) leg tips and (b) telson (getting contacted with sediment while normally not penetrating it) on one side and antennae (exclusively exposed to water given the living habits of this crayfish species) is correlated but in a negative way, indicating that telsons of O. limosus are kept in water for most of the time, unlike leg tips.

\section{Discussion}

Table 6 gives the parameters required for calculation/prediction of complex formation constants (empirical data: $[47,48]$ ) of several trivalent metals, including $\mathrm{Al}, \mathrm{Cr}$ and many REEs. For Eu [48], but in theory also other REEs such as $\mathrm{Ce}, \mathrm{Yb}, \mathrm{Sm}$, or Nd using appropriate solvents, electrochemical data from $[47,49]$ can be used to calculate complex formation constants in DMF. However, there are some difficulties: the reduction signal of $\mathrm{Yb}^{3+/ 2+}[48]$ in DMF does match that of the polysaccharide protons of chitin in same solvent at $-1.5 \mathrm{~V}$ whereas Ce gives poorly reproducible data on adsorption unless the redox state is tightly controlled. Reduction of $\mathrm{Sm}$ is feasible when there are ligands, though $a$ and $b$ in Equations (3) and (7) are empirical parameters, which in turn were calculated by this author using tables of complex formation constants (data from [42,43]). The sum of Hammett parameters (taken from [31]) for the ligand donor sites (e.g., 0 [carboxylate]-0.66 [- $\mathrm{NH}_{2}$ group] for glycinate or anthranilate, -0.75 for sarcosinate or -0.37 for glycolate or lactate, $2 \times[-0.66]=-1.32$ for ethylene diamine, etc.) can be compared to partition for environmental sites. For HOX acids (except of water, $\mathrm{H}_{2} \mathrm{O}_{2}, \mathrm{HSO}_{4}{ }^{-}$) (e.g., nitric, formic, benzoic, methanesulfonic, hydroxamic acids, phenol, glyconitrile, or $\mathrm{HCO}_{3}{ }^{-}$) the following equation applies (own calculation):

$$
\mathrm{pKa}=9.97-12.48 \sigma_{X}
$$

Table 6. $a$ and $\mathrm{b}$ parameters for mono- to tridentate ligands and certain trivalent ions $\mathrm{Al}, \mathrm{Cr}$, several REEs. The values in square brackets for $\mathrm{a}_{1 \mathrm{~d}}$ and $\mathrm{b}_{1 \mathrm{~d}}$ hold for $\mathrm{OX}^{-}$donors excluding nitrate (carboxylates, sulfate, carbonate, phenolate), for bidentate ligands complex formation constants for glycinate, glycolate, oxalate, or hydroxamates were used. For chitin, $\Sigma \sigma \approx-0.44$ and bidentate binding do hold.

\begin{tabular}{|c|c|c|c|c|c|c|}
\hline M(III) & $a_{1 d}$ & $b_{1 d}$ & $a_{2 d}$ & $b_{2 d}$ & $a_{3 d}$ & $b_{3 d}$ \\
\hline $\mathrm{Al}$ & & & 12.48 & 6.92 & & \\
\hline $\mathrm{Cr}$ & & & -8.50 & 4.52 & & \\
\hline $\mathrm{Y}$ & & & 2.57 & 5.67 & & \\
\hline $\mathrm{La}$ & {$[-10.08]$} & [6.90] & 8.32 & 6.21 & -2.52 & 3.09 \\
\hline $\mathrm{Ce}$ & $\begin{array}{c}-8.00 \\
{[-11.50]}\end{array}$ & $\begin{array}{c}2.89 \\
{[7.58]}\end{array}$ & 3.70 & 2.56 & -2.58 & 3.31 \\
\hline $\operatorname{Pr}$ & & & 3.95 & 2.57 & -2.74 & 3.35 \\
\hline $\mathrm{Nd}$ & & & 4.02 & 2.60 & -2.77 & 3.43 \\
\hline $\mathrm{Sm}$ & {$[-11.07]$} & [7.54] & 8.08 & 6.02 & & \\
\hline $\mathrm{Eu}$ & $\begin{array}{c}-8.98 \\
{[-11.92]}\end{array}$ & $\begin{array}{c}3.44 \\
{[7.97]}\end{array}$ & 9.45 & 7.02 & & \\
\hline $\mathrm{Gd}$ & {$[-11.55]$} & [7.71] & 9.91 & 7.05 & & \\
\hline Dy & {$[-14.55]$} & [8.90] & 9.65 & 7.04 & & \\
\hline $\mathrm{Tm}$ & {$[-12.58]$} & [8.02] & & & & \\
\hline $\mathrm{Yb}$ & {$[-13.22]$} & [8.29] & & & & \\
\hline $\mathrm{Lu}$ & {$[-12.23]$} & [7.86] & 10.59 & 7.30 & & \\
\hline
\end{tabular}


This does describe adsorption performance of chitin somewhat influenced by ambient ligands which may bind to REEs and other metal ions. This can either produce some complex withhold in its dissolved state (e.g., with $\mathrm{Sm}$ ) and/or (on the contrary) facilitate/increase adsorption by stronger adsorption of large complex molecules. Ligands may even act as anchor groups connecting metal ions and chitin, such as with glycine and other amino acids [18,22]. Values used for calibration and in Equations (4), (6)-(8) were calculated and most of them (the pertinent ones) are given in Table 6 (additional values can be obtained from Equation (3), Table 4 and data in [28]).

These data then are used to identify binding sites from observed sequences of binding preferences, e.g., BCF values following Equation (2).

This gives an account for differences in binding of REEs in different organs of a plant or animal or fungus; here, we limit our focus of attention to chitin. Chitin is one of the ligands where the modified formula must be used for its containing carboxamide ligands. Interestingly, metal retention to chitin does produce an additional reductive half-wave in $\mathrm{DMF} / \mathrm{Li}^{+}$solutions regardless of the kind of metal which was bound [14,17]. It is attributed to an increased acidity of sugar $\mathrm{OH}$ groups caused by complexation. This transition is located at $-1.50 \mathrm{~V}$ vs. SCE which translates into $-1.07 \mathrm{~V}$ vs. NHE in DMF (the larger difference vs. SCE owing to the higher proton affinity of this solvent) and thus $\mathrm{pK}_{\mathrm{a}\left(\mathrm{M}^{\mathrm{X}}{ }_{-} \mathrm{OH}\right) ; \mathrm{dmf}} \approx 18$, comparable to anion acids $\left(\mathrm{HSO}_{4}{ }^{-}, \mathrm{HC}_{2} \mathrm{O}_{4}{ }^{-}\right)$[43] or glycine (own measurements) in this solvent. Using the equations

$$
\begin{gathered}
\mathrm{pK}_{\mathrm{a}(\mathrm{dmf})}=23.48-22.91 \sigma_{\text {para }} \\
\mathrm{pK}_{\mathrm{a}(\mathrm{dmf})}=10.82-9.12 \sigma_{\mathrm{R}} \text { for } \mathrm{RCOOH}
\end{gathered}
$$

derived by us for acidities of oxoacid solutions in DMF, one can estimate $\sigma_{\text {para }}$ for the metal-loaded $\mathrm{OH}$ groups to be +0.24 (comparing to metal-free $\mathrm{OH}=-0.37$ ). By now, there

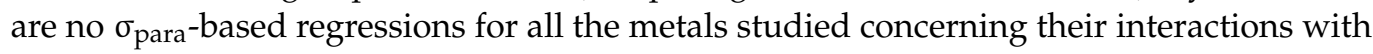
chitin, but there is a focus on those which are most important in our own work.

\subsection{Photoassisted Redox Reactions Occurring When Adsorbed to Chitin}

$\mathrm{Eu}(\mathrm{III})$ can promote photooxidation (cleavage of $\mathrm{CH}$ bonds) of organics and become reduced also when it is adsorbed to chitin [50]. Besides being injected by vegetation (oxalic acid also by lichens [10]), chemical species enhancing or bridging adsorption of Eu can be subject to degradation by bacteria (humic acids also by earthworms). Potential changes between the two chitin-modified electrodes thus must be anticipated and are going to be studied in our continuing experiments (also see outlook). Applications are concerned with sensors rather than fuel cells.

Among established substrates of photooxidation by Eu(III), the only one to enhance adsorption is glycine while humic acid, caffeic acid, citric and malonic acid all do reduce binding of Eu towards chitin. Generally speaking, chitin's adsorption capacity for Eu (and $\mathrm{Ce}, \mathrm{Dy}, \mathrm{Pb}$ ) is considerably higher than for other ions including other REEs [19,37]. Hence, one would predict that glycine photo-processing to afford ethanolamine, HCN and $\mathrm{CO}_{2}$ [51] would mainly occur at the chitin/solvent interface while the photooxidations of the other substrates take place in solution mainly. However, retention means an electrode placed at the top of chitin or right in it will maintain a rather positive potential, then acting as an anode while the leached $\mathrm{Eu}^{2+}$ gives a downstream electrode potential more positive than standard (cp. $[48,50])$ and thus makes the downstream electrode the cathode. We use $\mathrm{Ta}$ (foil or wire) as an electrode material [50] to avoid both

(1) heterogeneous-catalytic electrotransformations of organic compounds (to be anticipated on $\mathrm{Pt}$ ) and

(2) electrode corrosion (sizable with $\mathrm{Cu}$ ). 


\subsection{Change of Chitin Functions during Evolution}

The distribution of chitin among taxa [52] does strongly suggest it was present in many animals or their predecessor taxa in late Precambrian much before any hard structures other than mouthpieces (of putative mollusk Kimberella) were formed from it, omitting open issues on taxonomy of late Precambrian organisms capable of active movement and on details of the Cambrian explosion. When there was chitin way back in the Precambrian with common antecessors of certain pairs of taxa separating then (i.e., 550-575 mio. y $\mathrm{BP})$ or even earlier (fungi and animals) while totally or mainly absent in others, genetic data of either can be used to determine when it came into being even though chitin biosynthetic pathways in fungi and in animals differ somewhat while those in animals are conserved. However, the sorbent properties of chitin and the origins of mouthpieces combine to yield a meaningful interpretation: in the very beginnings, namely feeding, or retrieval of trace mineral nutrients partially relied on placing chitin fibers/appendices into the sediment. Covering structures, antennae, or legs would form only later (i.e., during Cambrian at the earliest $[12,13,52-55])$. Yet, given the data on adsorption extent $[3,14,22]$ and kinetics $[10,18,22]$, combined with the chance to leach them from some chitin surface by either acid or complexation, that is, by licking. Besides organisms such as Hallucigenia sparsa, it is telling that gill baskets of lancelets also contain chitin, which otherwise is rare in "genuine" vertebrates [55].

In previous and further course of evolution, chitin-bearing organisms developed many modes of interactions with those displaying cell walls that consist of other materials. Later, symbioses rendered chitin and its adsorption features available to organisms uncapable of making it themselves, as in plants (algae, cyanobacteria) teaming with fungi. Plants (Archaeoplastida) and cyanobacteria now make use of chitin's unique properties by way of (mostly obligate) symbiosis with fungi (lichens). In arboreal mykorrhiza there is another version of the same effect, with mykorrhiza known to be involved in transport of metals, too, implying adsorption and desorption of ambient metal ions by chitin in mycelia. Different kinds/materials of cell walls are also shown in the diagram (Figure 7):

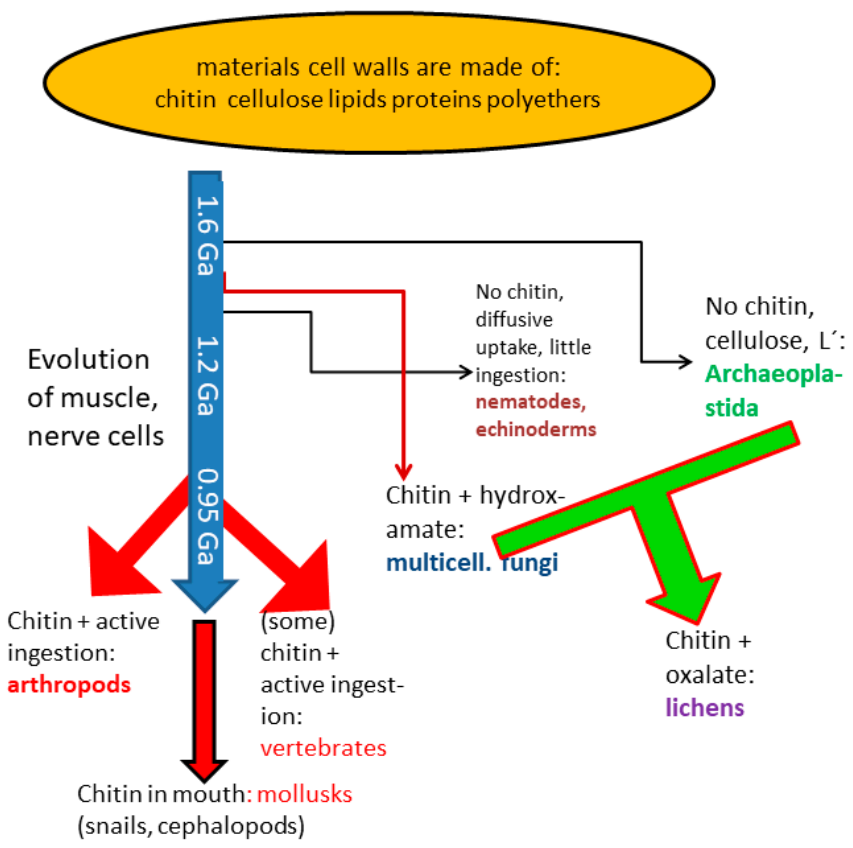

Figure 7. Chitin acts as a nutrient- and metal-retrieving sorbent within soft sediment (Ediacaran creatures purported to represent early animals used to be benthic or dwell within the sediment rather than swimming). (Multicellular) fungi (yeasts do not make chitin) use the same effect in mycelia. Here, uptake, transport, and release are likewise controlled by redox processes. REE contents in lichens may be rather high. Other kinds of cell walls existing in bacteria (B. subtilis) can discriminate and enrich terminal HREEs Tm, $\mathrm{Yb}$, and Lu against all lighter REEs and other trivalent ions. 


\section{Conclusions}

The prevalent role of chitin in terms of forming the outer covers, locomotive organs, and mouthpieces in a number of species which exceeds any other group by far (there are $>1.4$ mio. recognized species of beetles alone, even disregarding other arthropods) and other biopolymers by orders of magnitude in quantity can be traced back to its sorbent properties $[3,5,34,54]$. These can be exploited far beyond simple purification of wastewater flows $[5,38,54]$. Since adsorption depends on the oxidation state of some metal ions, such as $\mathrm{Eu}, \mathrm{Mn}$, and $\mathrm{U}$, charge separation producing electrochemical potentials can be achieved by passing a slow solvent flow through a chitin layer where chemical or photochemical reduction [50] or oxidation takes place. Because chitin is plentiful, optically transparent and readily available as scrap, and besides being very robust towards both oxidation and thermolysis, such devices should find their fields of application, e.g., in fuel cells and environmental sensors. It is anticipated that knowledge of such effects will improve understanding of peculiar effects seen in arthropod outer covers such as photovoltaic or thermoelectric activity in hornet Vespa orientalis [55].

\section{Outlook: Additional Studies in Lab and Open-Field}

Studies can be conducted in very different conditions, even without exceeding the limits of "extremophilic" arthropods (Artemia salina, crabs and shrimps inhabiting rather hot water pools) or lichens in the Antarctic given the chemical and thermal robustness of chitin. Certain uncommon biotopes and their adapted populations are particularly vulnerable, urging use of the chitin method for studies of local conditions, pollution inputs and metal mobilities, e.g., associated with formation of chloro-, sulfato-, or carbonatocomplexes in cold to mesothermal salinic media. These are inhabited by both arthropods and some fish (Cyprinodon spp.).

\section{(a) Studying Salinic Conditions in Water Bodies}

Among the vast number of living organisms covered by chitin, brine shrimp Artemia salina is easy to grow and keep (endures up to $>20 \% \mathrm{NaCl}$ ), enabling its use as a mobile electrode carrier in the following setup (Figure 8):

\section{Inter-chitin transfer of metal ions influenced by organics, $\mathrm{Cl}^{-}$}

- "donor": Artemia salina, gammarids, "Asellus aquaticus, Geosesarma crabs raised in high-M conditions, electrode (grey, In, Sn, or Ti) glued to carapax, respectively

- "acceptor": chitin grafted on metal (alloy), ions/complexes migrate downward

- mesh (nylon, glass fiber) keeps distance between donor(s) and counter-electrode constant

- Injection, biological or chemical consumption of organics at/near chitinplated electrode surface

- Transfer rate produces (temporal variation of) voltage

- LaNi $_{5-x} \mathrm{Co}_{y} \mathrm{Al}_{7}$ hydride storage agents as bottom counter-electrodes $\left(\varepsilon \approx \varepsilon_{\text {La }}, \mathrm{REE}-\right.$ selective)?
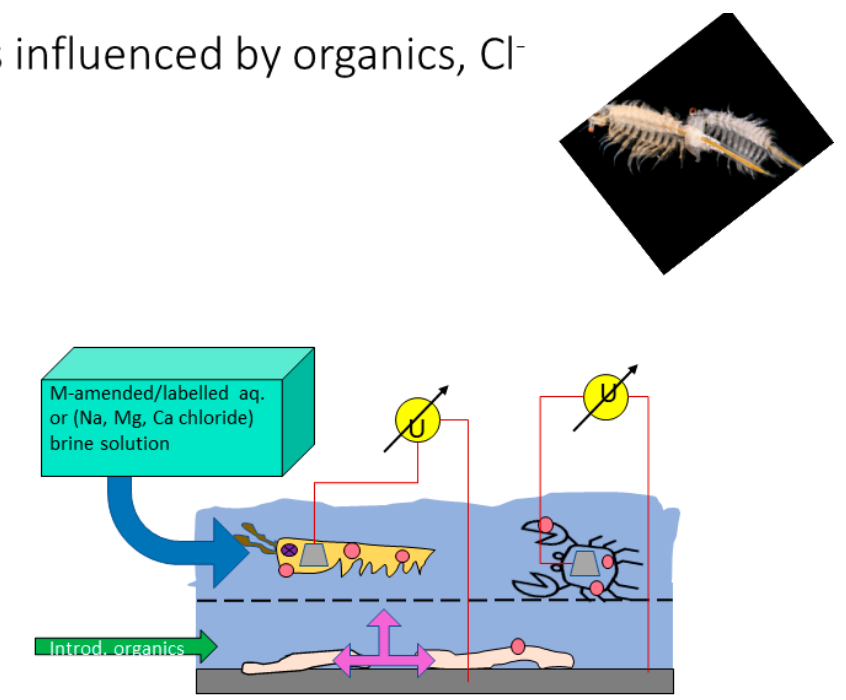

Figure 8. Animals swimming above (left) or running on (right) the separating mesh are kept at a given distance from the counter-electrode. This does control carry-over of metal ions from metal ions to chitin fixed to bottom electrode.

A "freshwater version" could be realized with gammarids or aq. woodlice (Asellus aquaticus) which are notorious for their robustness concerning both acidic $\mathrm{pH}$ 
and chemicals including dissolved chlorine. Other test organisms are crabs inhabiting extreme-condition tiny water pools such as phytotelmata (Geosesarma spp.) or-for moderately salinic counterparts - hermit crabs frequently inhabiting tidal rock pools.

(b) Adsorption vs. Transport around and Inside Wells, Springs, and Seepage Sites

Detection of non-equilibrium can be extended to artificial constructions as shown above (Figure 1) for Mo dynamics related to nitrate reductase and likely to wells (Figure 9). Microorganisms and excited $\mathrm{Eu}(\mathrm{III})$ compete for the same substrate to be oxidized (glucose, ethanolamine) and nitrate is either used by REE ions to induce (catalyze) nitrations of aromatics [56] such as benzyl alcohol, alkyl phenols or C,C-diphenylglycine. Besides REE catalysis of aromatic nitrations, nitrate can become reduced by nitrate-reducing bacteria (NRBs, chemolithotrophs) whereas chitin flakes in water (top and inside well) and sediment are used to measure partition. Controls are obtained in darkness or omitting living NRBs (Figure 9):

- Chitin detects non-equilibria $\square=$ flake symbols)

- REE catalysis of nitration of aromatics in water, e.g. benzyl alcohol

- Competes with nitrate reduction by bacteria (NRBs) [bottom of well, green]

- glucose is used by both NRBs and excited Eu(III)

- Transport of Eu and Mo from surrounding pond (top) into well - Control by omitting a) light and b) NRBs,
measure log P on chitin in either case

- Alternative: ethanolamine oxidation by yeast, bacteria vs. photooxidation by Eu (Co required for EA degradation)

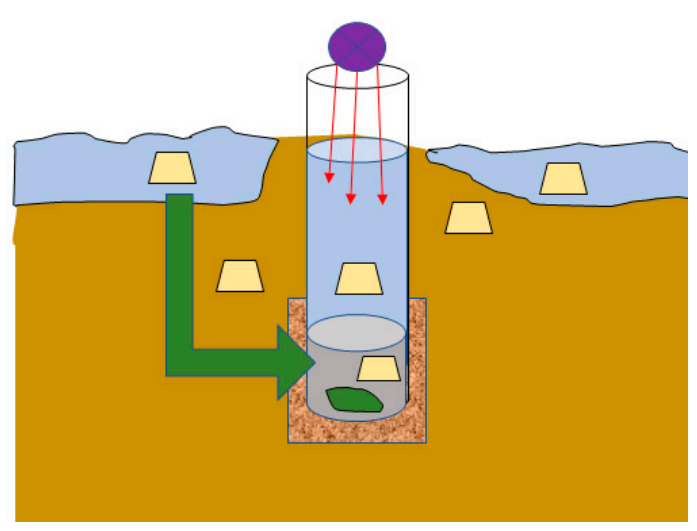

Figure 9. Model of a natural spring where biorelevant trace metals and Eu pass through a sediment layer (e.g., the support of a small island) before re-appearing in a spring or well. Transport and biochemical processes can be surveyed by both chitin adsorption/partition on flakes and photoreduction of Eu.

Solid matrices such as gelatin enable activation of compounds which do not undergo photooxidation in solutions, such as aniline, salicylic acid, and N,N-dimethyl glycine [57]. Both occurrence of this reaction and products may differ depending on the surroundings, including feedback to chitin flakes (Figures 8 and 9). We plan corresponding experiments in the near future.

Author Contributions: Data curation, F.B.; Formal analysis, S.F.; Writing manuscript, S.F.; Supervision, S.F. All authors have read and agreed to the published version of the manuscript.

Funding: Open Access Funding by the Publication Fund of the TU Dresden.

Institutional Review Board Statement: Not applicable.

Informed Consent Statement: There were no experiments on human beings or related to their medical treatment, so consent neither need nor could be obtained.

Data Availability Statement: Not applicable.

Acknowledgments: First of all, my appreciation and thanks go to my enthusiastic team involved in this research since 2013, also being aware of what this might mean in terms of biology and evolution (cp. the theses by A. Bauer, F. Blind, P. Budelmann, M. Erler, T. Gebauer, D. Retschke, and Y.J. Luoga), and of course to the people who did the analyses and helped to develop the corresponding methods, 
finally transferring chitin's fascinating properties into the field of energy conversion topics. In addition, I owe much inspiration to colleagues from abroad, especially Italy, Mongolia and Russia (Stefano Loppi, Andrea Vannini, Marina Frontasyeva, Ariuna Lkhagva).

Conflicts of Interest: The authors declare no conflict of interest.

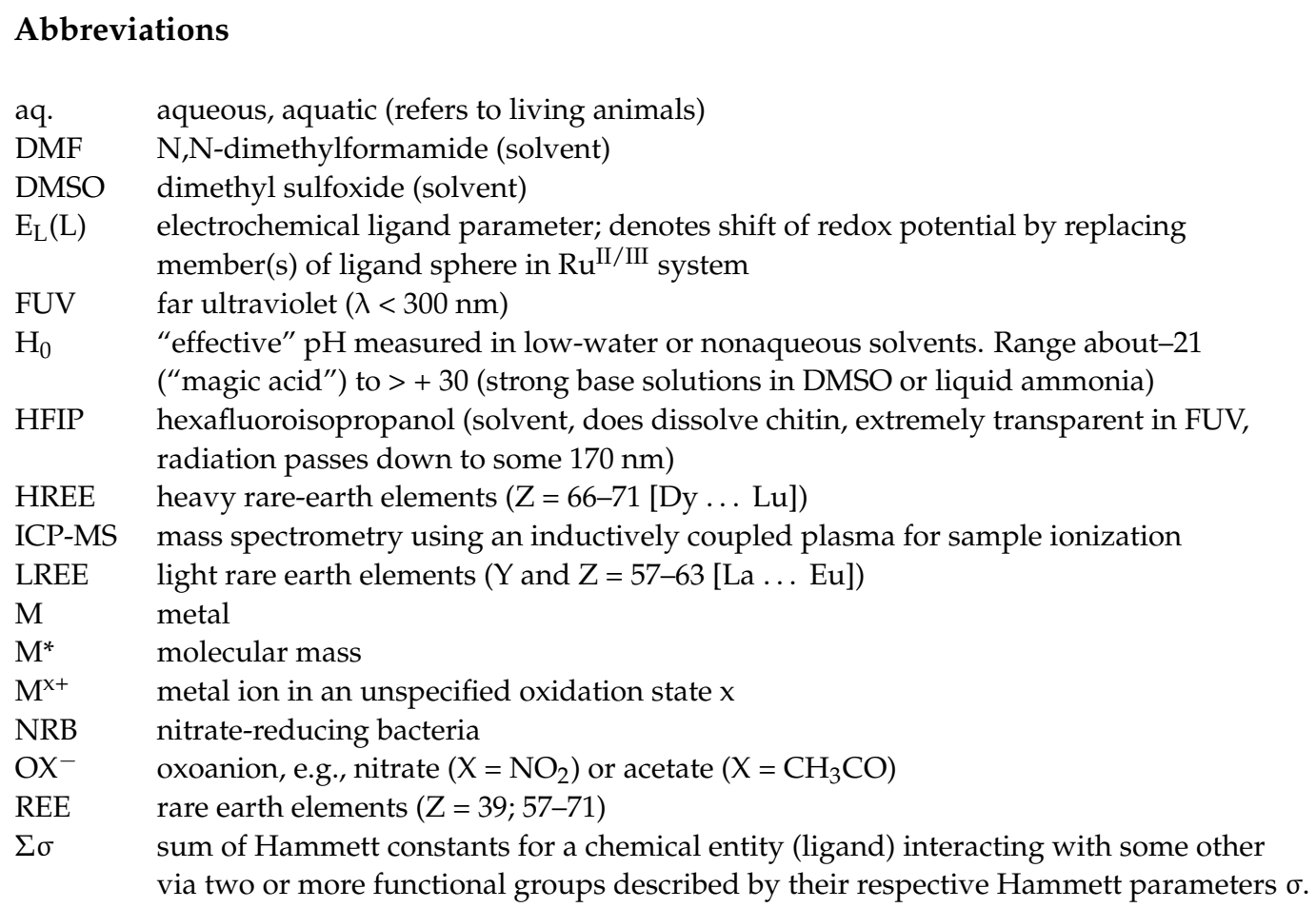

\section{References}

1. Zhao, D.; Yu, S.; Sun, B.; Gao, S.; Guo, S.; Zhao, K. Biomedical Applications of Chitosan and Its Derivative Nanoparticles. Polymers 2018, 10, 462. [CrossRef] [PubMed]

2. Yamada, K.; Chen, T.; Kumar, G.; Vesnovsky, O.; Topoleski, L.D.T.; Payne, G.F. Chitosan Based Water-Resistant Adhesive. Analogy to Mussel Glue. Biomacromolecules 2000, 1, 252-258. [CrossRef] [PubMed]

3. Anastopoulos, I.; Bhatnagar, A.; Bikiaris, D.N.; Kyzas, G.Z. Chitin Adsorbents for Toxic Metals: A Review. Int. J. Mol. Sci. 2017, 18, 114. [CrossRef] [PubMed]

4. Barros, F.C.; Vasconcellos, L.C.G.; Carvalho, T.V.; do Nascimento, R.F. Adsorption of organics to chitin: Removal of Petroleum Spill in Water by Chitin and Chitosan. Orbital-Electron. J. Chem. 2014, 6, 70-74. [CrossRef]

5. Pinto, P.X.; Al-Abed, S.R.; McKernan, J. Comparison of the efficiency of chitinous and ligneous substrates in metal and sulfate removal from mining-influenced water. J. Environ. Manag. 2018, 227, 321-328. [CrossRef]

6. Pearlmutter, N.L.; A Lembi, C. Localization of chitin in algal and fungal cell walls by light and electron microscopy. J. Histochem. Cytochem. 1978, 26, 782-791. [CrossRef]

7. Zitko, V.; Bishop, C.T. Oxidation of polysaccharides by lead tetraacetate in dimethyl sulfoxide. Canad. J. Chem. 1966, 44, 1749-1756. [CrossRef]

8. Liu, P.; Liu, H.; Schäfer, T.; Gutmann, T.; Gibhardt, H.; Qi, H.; Tian, L.; Zhang, X.C.; Buntkowsky, G.; Zhang, K. Unexpected selective alkaline periodate oxidation of chitin for the isolation of chitin nanocrystals. Green Chem. 2020, 23, 745-751. [CrossRef]

9. Machałowski, T.; Amemiya, C.; Jesionowski, T. Chitin of Araneae origin: Structural features and biomimetic applications: A review. Appl. Phys. A 2020, 126, 1-17. [CrossRef]

10. Loppi, S.; Vannini, A.; Monaci, F.; Dagodzo, D.; Blind, F.; Erler, M.; Fränzle, S. Can Chitin and Chitosan Replace the Lichen Evernia prunastri for Environmental Biomonitoring of $\mathrm{Cu}$ and $\mathrm{Zn}$ Air Contamination? Biology 2020, 9, 301. [CrossRef]

11. Arthur Stankiewicz, B.; van Bergen, P.F.; Duncan, I.J.; Carter, J.F.; Briggs, D.E.; Evershed, R.P. Recognition of chitin and proteins in invertebrate cuticles using analytical pyrolysis/gas chromatography and pyrolysis/gas chromatography/mass spectrometry. Rapid Comm. Mass Spectrom. 1996, 10, 1747-1757. [CrossRef]

12. Ehrlich, H.; Rigby, J.K.; Botting, J.P.; Tsurkan, M.V.; Werner, C.; Schwille, P.; Geisler, T. Discovery of 505-million-year old chitin in the basal demosponge Vauxia Gracilenta. Nat. Sci. Rep. 2013, 3, 3497. [CrossRef]

13. Gupta, N.S.; Michels, R.; Briggs, D.E.G.; Evershed, R.P.; Pancost, R.P. The organic preservation of fossil arthropods: An experimental study. Proc. Biol. Sci. 2006, 273, 2777-2783. [CrossRef] [PubMed] 
14. Fränzle, S.; Erler, M.; Blind, F.; Ariuntsetseg, L.; Narangarvuu, D. Chitin adsorption in environmental monitoring: Not an alternative to moss monitoring but a method providing (lots of) bonus information. J. Sci. Arts. Univ. Valahia Chem. 2019, 19, 659-674.

15. Hassanzadeh, P.; Sun, W.; De Silva, J.P.; Jin, J.; Makhnejia, K.; Cross, G.; Rolandi, M. Mechanical properties of self-assembled chitin nanofiber networks. J. Mater. Chem. B 2013, 2, 2461-2466. [CrossRef] [PubMed]

16. Bell, H.L.; Nebeker, A.V. Preliminary studies on the tolerance of aquatic insects to low pH. J. Kans. Entomol. Soc. 1969, 42, 230-236.

17. Budelmann, P. Verbreitung der Flusskrebse (Decapoda) in der südlichen Oberlausitz und die Eignung des invasiven Kamberkrebses (Orconectes limosus) für Chitin-Basiertes Monitoring von Schwermetallen in Limnischen Ökosystemen. Master's Thesis, IHI Zittau/TU Dresden, Zittau, Germany, 2021.

18. Gebauer, T. Methodische Optimierung des Übertrags von Metallionen aus Umweltprobenmodellen auf Chitinoberflächen und von Diesen zu Zwecken Analytischen Biomonitorings Sowie Untersuchungen zur Diffusion/Ausbreitung von Analyten in Chitinproben. Master's Thesis, IHI Zittau/TU Dresden, Zittau, Germany, 2016.

19. Retschke, D. Orientierende Untersuchungen zur Adsorption von Schwermetallen (Nickel) unter dem Einfluss Ausgewählter Komplexliganden Sowie in Arealen Potenzieller und Manifester Methanogenese. Master's Thesis, IHI Zittau/TU Dresden, Zittau, Germany, 2017.

20. Kim, Y.J.; Park, C.R. Analysis of problematic complexing behavior of ferric chloride with N,N-Dimethylformamide using combined techniques of FT-IR, XPS, and TGA/DTG. Inorg. Chem. 2002, 41, 6211-6216. [CrossRef] [PubMed]

21. Masui, M.; Sayo, H.; Tsuda, Y. Anodic Oxidation of Amines. Part 1. Cyclic Voltammetry of Aliphatic Amines at a Stationary Glassy-carbon Electrode. J. Chem. Soc. B 1968, 973-976. [CrossRef]

22. Erler, M. Untersuchung des Bindungsverhaltens Ausgewählter Elemente und Ihrer Bodenrelevanten Komplexe an Chitin. Master's Thesis, IHI Zittau/TU Dresden, Zittau, Germany, 2020.

23. Fränzle, S.; Bauer, A. This observation was not published in print but reported in conference lectures. 2014.

24. Bauer, A. Orientierende Untersuchungen zur Bindung von Metallionen an Chitin und zur Davon Abhängigen Eignung von Arthropoden zur Bestimmung von Metallionenkonzentrationen in der Umwelt. Master's Thesis, IHI Zittau/TU Dresden, Zittau, Germany, 2014.

25. Chen, K.; Bocknek, L.; Manning, B. Oxidation of $\mathrm{Cr}(\mathrm{III})$ to $\mathrm{Cr}(\mathrm{VI})$ and Production of Mn(II) by Synthetic Manganese(IV) Oxide. Crystals 2021, 11, 443. [CrossRef]

26. Nico, P.S.; Zasoski, R.J. Mn(III) Center Availability as a Rate Controlling Factor in the Oxidation of Phenol and Sulfide on $\delta$-MnO 2 . Environ. Sci. Technol. 2001, 35, 3338-3343. [CrossRef]

27. Sharma, S.; Rai, O.P. Evaluation of stability constants of metal complexes with chloramphenicol. Intern. J. Adv. Sci. Res. 2017, 6. [CrossRef]

28. Fränzle, S. Chemical Elements in Plants and Soil, Habilitation thesis of SF, extended and translated version, originally submittted to Vechta Univ. (Vechta, Germany) in 2007 which gave venia legendi; Springer: Berlin/Heidelberg, Germany, 2010.

29. Fränzle, S. Estimating and predicting chemical potentials, distributions, speciation modes and mobilities of radiometals in soil, water and biomass. J. Environ. Radioact. 2013, 102, 109-116. [CrossRef]

30. Masui, H.; Lever, A.B.P. Correlations between the ligand electrochemical parameter, $\mathrm{E}_{\mathrm{L}}(\mathrm{L})$, and the Hammett substituent parameter, sigma. Inorg. Chem. 1993, 32, 2199-2201. [CrossRef]

31. Hansch, C.; Leo, A.; Taft, R.W. A Survey of Hammett Substituent Constants and Resonance and Field Parameters. Chem. Rev. 1991, 97, 165-195. [CrossRef]

32. Lever, A.B.P. Electrochemical parametrization of metal complex redox potentials, using the ruthenium(III)/ruthenium(II) couple to generate a ligand electrochemical series. Inorg. Chem. 1990, 29, 1271-1285. [CrossRef]

33. Pol, A.; Barends, T.R.M.; Dietl, A.; Khadem, A.F.; Eygensteyn, J.; Jetten, M.S.M.; den Camp, H.J.M.O. Rare earth metals are essential for methanotrophic life in volcanic mudpots. Environ. Microbiol. 2013, 16, 255-264. [CrossRef] [PubMed]

34. Picone, N.; den Camp, H.J.M.O. Role of rare earth elements in methanol oxidation. Curr. Opin. Chem. Biol. 2019, 4, 39-44. [CrossRef]

35. Featherston, E.R.; Cotruvo, J.A., Jr. The biochemistry of lanthanide acquisition, trafficking, and utilization. Biochim. Biophys. Acta (BBA)-Mol. Cell Res. 2021, 1868, 118864. [CrossRef] [PubMed]

36. Fränzle, S. Hitherto unpublished work. Correlations between (sum of) Hammett constant(-s) of ligand donor groups and the electrochemical ligand parameter (which is defined by dividing total potential effect by denticity of ligand). 2020.

37. Vijayaraghavan, K.; Balasubramanian, R. Single and binary biosorption of cerium and europium onto crab shell particles. Chem. Eng. J. 2010, 163, 337-343. [CrossRef]

38. Muzzarelli, R.A.A.; Rocchetti, R.; Marangio, G. Separation of zirconium, niobium, cerium and ruthenium on chitin and chitosan columns for the determination of cesium in nuclear fuel solutions. J. Radioanal. Chem. 1972, 10, 17-25. [CrossRef]

39. Karraker, R.H. Stability Constants of Some Rare-Earth-Metal Chelates. Ph.D. Thesis, Iowa State University, Ames, IA, USA, 1961.

40. Dmytryk, A.; Tuhy, L.; Samoraj, M.; Chojnacka, K.W. Biological Functions of Cadmium, Nickel, Vanadium, and Tungsten. In Recent Advances in Trace Elements; Chojnacka, K.W., Saeid, A., Eds.; Wiley: Hoboken, NY, USA, 2018; pp. 219-234. [CrossRef]

41. Gonzalez-Davila, M.; Santana-Casiano, M.; Millero, F.J. The Adsorption of $\mathrm{Cd}(\mathrm{II})$ and $\mathrm{Pb}(\mathrm{II})$ to Chitin in Seawater. J. Colloid Interf. Sci. 2009, 137, 102-107. [CrossRef] 
42. Ramirez-Wong, D.; Ramirez-Cardona, M.; Sánchez-Leija, R.J.; Rugerio, A.; Mauricio-Sánchez, R.A.; Hernández-Landaverde, M.A.; Carranza, A.; Pojman, J.A.; Garay-Tapia, A.M.; Prokhorov, E.; et al. Sustainable-solvent-induced polymorphism in chitin films. Green Chem. 2016, 18, 4303-4311. [CrossRef]

43. Kolthoff, I.M.; Chantooni, M.K.; Smagowski, H. Acid-base strengths in N,N-dimethylformamide. Anal. Chem. 1970, 42, 1622-1628. [CrossRef]

44. Abdel-Rahman, R.M.; Hrdina, R.; Abdel-Mohsen, A.-M.; Fouda, M.; Soliman, A.; Mohamed, F.; Mohsin, K.; Pinto, T.D. Chitin and chitosan from Brazilian Atlantic Coast: Isolation, characterization and antibacterial activity. Int. J. Biol. Macromol. 2015, 80, 107-120. [CrossRef] [PubMed]

45. Bernabé, P.; Becherán, L.; Cabrera, G.; Nesic, A.; Alburquenque, C.; Tapia, C.V.; Taboada, E.; Alderete, J.B.; Ríos, P.D.L. Chilean $\mathrm{crab}$ (Aegla cholchol) as a new source of chitin and chitosan with antifungal properties against Candida spp. Int. J. Biol. Macromol. 2020, 149, 962-975. [CrossRef] [PubMed]

46. Wood, S.A. The aqueous geochemistry of the rare-earth elements: Critical stability constants for complexes with simple carboxylic acids at $25^{\circ} \mathrm{C}$ and 1 bar and their application to nuclear waste management. Eng. Geol. 1993, 34, 229-259. [CrossRef]

47. Couffin, F. Potentiels d'oxydo-reduction des elements lanthanides et actinides dans les solvants organiques; CEA (Internal report (data collection) for CEA (Centre d'Energie Atomique), France. Does cover all lanthanides, many sol-vents including DMF, and actinides Th, Pa, U ... Cm, Cf in DMF, DMSO, ethylene diamine, or tributyl phosphate; CEA: Saclay, France, 1980.

48. Holleck, L. Zur Komplexchemie der Seltenen Erden. Die polarographischen Strompotentialkurven des Europiums als Nachweismittel komplexer Bindung. Z. für Naturf. B 1947, 2, 81-89. [CrossRef]

49. Blind, F. Orientierende Untersuchungen zur Platinmetall freien Aktivierung von CH-Bindungen für Europium basierte Brennstoffzellenanwendungen. Master's Thesis, IHI Zittau/TU Dresden, Zittau, Germany, 2018.

50. Blind, F.; Kluge, M.; Fränzle. Unpublished GC/MS observation using silylation of photoredox products in DMF and alkylation of ions like cyanide.

51. Cody, G.D.; Gupta, N.S.; Briggs, D.E.; Kilcoyne, A.; Summons, R.E.; Kenig, F.; Plotnick, R.E.; Scott, A. Molecular signature of chitin-protein complex in Paleozoic arthropods. Geology 2011, 39, 255-258. [CrossRef]

52. Keleşoglu, S. Comparative Adsorption Studies of Heavy Metal Ions on Chitin and Chitosan Biopolymers. Master's Thesis, Izmir School of Technology, Izmir, Turkey, 2007.

53. Jaafarzadeh, N.; Mengelizadeh, N.; Takdastan, A.; Farsani, M.H.; Niknam, N.; Aalipour, M.; Hadei, M.; Bahrami, P. Biosorption of heavy metals from aqueous solutions onto chitin. Int. J. Environ. Health Eng. 2015, 4, 7. [CrossRef]

54. Sannasi, A.; Hermann, H.R. Chitin in the cephalochordata, Branchisotoma floridae. Cell. Mol. Life Sci. 1970, $26,351-352$. [CrossRef]

55. Ishay, J.; Benshalom-Shimony, T.; Ben-Shalom, A.; Kristianpoller, N. Photovoltaic effects in the Oriental hornet, Vespa orientalis. J. Insect Physiol. 1992, 38, 37-48. [CrossRef]

56. Shi, M.; Cui, S. Perfluorinated rare earth metals catalyzed nitration of aromatic compounds. J. Fluor. Chem. 2002, 39, 551-556. [CrossRef]

57. Pulsfort, J. Biopolymere als Potenzielle Substrate der Photooxidation Durch f-Block-Metalle. Master's Thesis, IHI Zittau/TU Dresden, Zittau, Germany, 2021. 